\title{
Article
}

\section{Ten millennia of hepatitis B virus evolution}

Kocher, Arthur, Papac, Luka, Barquera, Rodrigo, Key, Felix M., Spyrou, Maria A., Rohrlach, Adam B., Aron, Faranziska, Stahl, Raphaela, Sayer, Duncan and Et, Al

Available at https://clok.uclan.ac.uk/39976/

Kocher, Arthur, Papac, Luka, Barquera, Rodrigo, Key, Felix M., Spyrou, Maria A., Rohrlach, Adam B., Aron, Faranziska, Stahl, Raphaela, Sayer, Duncan orcid iconORCID: 0000-0002-2769-1281 et al (2021) Ten millennia of hepatitis $B$ virus evolution. Science, 374 (6564). pp. 182-188. ISSN 0036-8075

It is advisable to refer to the publisher's version if you intend to cite from the work. http://dx.doi.org/10.1126/science.abi5658

For more information about UCLan's research in this area go to http://www.uclan.ac.uk/researchgroups/ and search for < name of research Group>.

For information about Research generally at UCLan please go to http://www.uclan.ac.uk/research/

All outputs in CLoK are protected by Intellectual Property Rights law, including Copyright law. Copyright, IPR and Moral Rights for the works on this site are retained by the individual authors and/or other copyright owners. Terms and conditions for use of this material are defined in the policies page.

\section{CLoK}

Central Lancashire online Knowledge www.clok.uclan.ac.uk






\section{Title: Ten millennia of hepatitis $B$ virus evolution}

Authors: Arthur Kocher ${ }^{1, *}$, Luka Papac ${ }^{2}$, Rodrigo Barquera ${ }^{2}$, Felix M. Key ${ }^{2,3}$, Maria A. Spyrou ${ }^{2,4}$, Ron Hübler ${ }^{2}$, Adam B. Rohrlach ${ }^{2,5}$, Franziska Aron $^{2}$, Raphaela Stahl', Antje Wissgott ${ }^{2}$, Florian van Bömmel ${ }^{6}$, Maria Pfefferkorn ${ }^{6}$, Alissa Mittnik ${ }^{2,7,8}$, Vanessa Villalba-Mouco ${ }^{2,9}$, Gunnar U. Neumann², Maïté Rivollat ${ }^{2,10}$, Marieke S. van de Loosdrecht ${ }^{2}$, Kerttu Majander ${ }^{2}$, Rezeda I. Tukhbatova ${ }^{2,11}$, Lyazzat Musralina ${ }^{2,12,13}$, Ayshin Ghalichi ${ }^{2}$, Sandra Penske ${ }^{2}$, Susanna Sabin ${ }^{2}$, Megan Michel $^{2,8}$, Joscha Gretzinger ${ }^{2}$, Elizabeth A. Nelson², Tiago Ferraz ${ }^{2}, 14$, Kathrin Nägele 2 , Cody Parker ${ }^{2,15}$, Marcel Keller ${ }^{2,16}$, Evelyn K. Guevara ${ }^{2,17}$, Michal Feldman ${ }^{2,4}$, Stefanie Eisenmann $^{2}$, Eirini Skourtanioti ${ }^{2}$, Karen Giffin ${ }^{2}$, Guido Alberto Gnecchi Ruscone ${ }^{2}$, Susanne Friederich ${ }^{18}$, Vittoria Schimmenti ${ }^{19}$, Valery Khartanovich ${ }^{20}$, Marina K. Karapetian ${ }^{21}$, Mikhail S. Chaplygin ${ }^{22}$, Vladimir V. Kufterin ${ }^{23}$, Aleksandr A. Khokhlov ${ }^{24}$, Andrey A. Chizhevsky ${ }^{25}$, Dmitry A. Stashenkov ${ }^{26}$, Anna F. Kochkina ${ }^{26}$, Cristina Tejedor-Rodríguez ${ }^{27}$, Íñigo García-Martínez de Lagrán ${ }^{28}$, Héctor Arcusa-Magallón ${ }^{29}$, Rafael Garrido-Pena ${ }^{30}$, José Ignacio Royo-Guillén ${ }^{31}$, Jan Nováček ${ }^{32,33}$, Stéphane Rottier ${ }^{10}$, Sacha Kacki ${ }^{10,34}$, Sylvie Saintot ${ }^{35}$, Elena Kaverzneva $^{36}$, Andrej B. Belinskiy ${ }^{37}$, Petr Velemínský ${ }^{38}$, Petr Limburský ${ }^{39}$, Michal Kostka ${ }^{40}$, Louise Loe $^{41}$, Elizabeth Popescu ${ }^{42}$, Rachel Clarke ${ }^{42}$, Alice Lyons ${ }^{42}$, Richard Mortimer ${ }^{42}$, Antti Sajantila ${ }^{17,43}$, Yadira Chinique de Armas $^{44}$, Silvia Teresita Hernandez Godoy ${ }^{45,46}$, Diana I. Hernández-Zaragoza ${ }^{47,48}$, Jessica Pearson ${ }^{49}$, Didier Binder $^{50}$, Philippe Lefranc ${ }^{51}$, Anatoly R. Kantorovich ${ }^{52}$, Vladimir E. Maslov ${ }^{53}$, Luca Lai ${ }^{54,55}$, Magdalena Zoledziewska $^{56}$, Jessica F. Beckett ${ }^{57}$, Michaela Langováa ${ }^{39}$, Alžběta Danielisováa ${ }^{39}$, Tara Ingman ${ }^{58}$, Gabriel García Atiénzar $^{59}$, Maria Paz de Miguel Ibánez ${ }^{59}$, Alejandro Romero ${ }^{59,60}$, Alessandra Sperduti ${ }^{61,62}$, Sophie Beckett ${ }^{63,64,65}$, Susannah J. Salter ${ }^{63,66}$, Emma D. Zilivinskaya ${ }^{23}$, Dmitry V. Vasil'ev ${ }^{67}$, Kristin von Heyking ${ }^{68}$, Richard L. Burger ${ }^{69}$, Lucy C. Salazar ${ }^{69}$, Luc Amkreutz ${ }^{70}$, Masnav Navruzbekov ${ }^{71}$, Eva Rosenstock ${ }^{72}$, Carmen Alonso-Fernández ${ }^{73}$, Vladimir Slavchev ${ }^{74}$, Alexey A. Kalmykov ${ }^{37}$, Biaslan Ch. Atabiev ${ }^{75}$, Elena Batieva ${ }^{76}$, Micaela Alvarez Calmet ${ }^{77}$, Bastien Llamas ${ }^{78,79,80}$, Michael Schultz ${ }^{81}$, Raiko Krauß $\beta^{82}$, Javier Jiménez-Echevarría ${ }^{73}$, Michael Francken ${ }^{83}$, Svetlana Shnaider ${ }^{84}$, Peter de Knijff ${ }^{85}$, Eveline Altena ${ }^{85}$, Katrien Van de Vijver ${ }^{86,87,88}$, Lars Fehren-Schmitz ${ }^{89,90}$, Tiffiny A. Tung ${ }^{91}$, Sandra Lösch ${ }^{92}$, Maria Dobrovolskaya ${ }^{53}$, Nikolaj Makarov ${ }^{53}$, Chris Read ${ }^{93}$, Melanie Van Twest $^{63}$, Claudia Sagona ${ }^{94}$, Peter C. Rams ${ }^{95}$, Murat Akar ${ }^{96}$, K. Aslihan Yener ${ }^{97}$, Eduardo Carmona Ballestero ${ }^{98,99}$, Francesco $\mathrm{Cucca}^{56,100}$, Vittorio Mazzarello ${ }^{100}$, Pilar Utrilla ${ }^{101}$, Kurt Rademaker ${ }^{102}$, Eva Fernández-Domínguez ${ }^{34}$, Douglas Baird ${ }^{49}$, Patrick Semal ${ }^{86}$, Lourdes Márquez-Morfín ${ }^{103}$, Mirjana Roksandic ${ }^{44,104,105}$, Hubert Steiner ${ }^{106}$, Domingo Carlos Salazar-García ${ }^{107,108,109}$, Natalia Shishlina ${ }^{36}$, Yilmaz Selim Erdal ${ }^{110}$, Fredrik Hallgren ${ }^{111}$, Yavor Boyadzhiev $^{112}$, Kamen Boyadzhiev ${ }^{12}$, Mario Küßner ${ }^{32}$, Duncan Sayer ${ }^{113}$, Päivi Onkamo ${ }^{114115}$, Robin Skeates ${ }^{34}$, 30 Manuel Rojo-Guerra ${ }^{27}$, Alexandra Buzhilova ${ }^{21}$, Elmira Khussainova ${ }^{13}$, Leyla B. Djansugurova ${ }^{13}$, Arman Z. Beisenov $^{116}$, Zainolla Samashev ${ }^{117,118}$, Ken Massy ${ }^{119}$, Marcello Mannino ${ }^{120,121}$, Vyacheslav Moiseyev ${ }^{20}$, Kristiina Mannermaa $^{122}$, Oleg Balanovsky ${ }^{123,124,125}$, Marie-France Deguilloux ${ }^{10}$, Sabine Reinhold ${ }^{126}$, Svend Hansen ${ }^{126}$, Egor P. Kitov ${ }^{23,116}$, Miroslav Dobes ${ }^{39}$, Michal Ernée ${ }^{39}$, Harald Meller ${ }^{18}$, Kurt W. Alt ${ }^{127,128,129}$, Kay Prüfer ${ }^{2}$, Christina Warinner, ${ }^{2,130}$, Stephan Schiffels ${ }^{2}$, Philipp W. Stockhammer ${ }^{2,119}$, Kirsten Bos ${ }^{2}$, Cosimo Posth ${ }^{2,4}$, Alexander Herbig 2 , Wolfgang Haak ${ }^{2,131}$, Johannes Krause, ${ }^{2, *}$, and Denise Kühnert ${ }^{1,132, *}$ 


\section{Affiliations:}

${ }^{1}$ Transmission, Infection, Diversification \& Evolution Group, Max-Planck Institute for the Science of Human History, Kahlaische Str. 10, 07745 Jena, Germany.

${ }^{2}$ Department of Archaeogenetics, Max-Planck Institute for the Science of Human History, Kahlaische Str. 10, 07745 Jena, Germany.

${ }^{3}$ Max Planck Institute for Infection Biology, Charitéplatz 1, 10117 Berlin, Germany.

${ }^{4}$ Archaeo- and Palaeogenetics group, Institute for Archaeological Sciences, Eberhard Karls University Tübingen, Rümelinstrasse 23, 72070 Tübingen, Germany.

10 University of Adelaide, Adelaide, SA 5005, Australia.

${ }^{6}$ Division of Hepatology, Department of Medicine II, Leipzig University Medical Center, Leipzig, Germany.

${ }^{7}$ Department of Genetics, Harvard Medical School, Boston, MA, USA.

${ }^{8}$ Department of Human Evolutionary Biology, Harvard University, 11 Divinity Ave., Cambridge, MA 02138 USA.

159 Institute of Evolutionary Biology, CSIC-Universitat Pompeu Fabra, Barcelona, Spain.

${ }^{10}$ Université de Bordeaux, CNRS, PACEA UMR 5199, Pessac, France.

${ }^{11}$ Laboratory of Structural Biology, Kazan Federal University, Kazan, Russia.

${ }^{12}$ Al-Farabi Kazakh National University, Almaty, Kazakhstan.

${ }^{13}$ Institute of Genetics and Physiology, 050060, al-Farabi ave., 93, Almaty, Kazakhstan.

$20 \quad{ }^{14}$ Departmento de Genética e Biologia Evolutiva, Instituto de Biociências, Universidade de São Paulo, São Paulo, SP, Brazil.

${ }^{15}$ Arizona State University School of Human Evolution and Social Change, Tempe Arizona, USA.

${ }^{16}$ Estonian Biocentre, Institute of Genomics, University of Tartu, Tartu, Estonia.

${ }^{17}$ Department of Forensic Medicine, University of Helsinki, Helsinki, Finland.

$25{ }^{18}$ State Office for Heritage Management and Archaeology Saxony-Anhalt and State Museum of Prehistory, D06114 Halle, Germany.

${ }^{19}$ Museo Archeologico Regionale “Antonino Salinas”, Palermo, Via Bara all’Olivella 24, 90133, Italy.

${ }^{20}$ Peter the Great Museum of Anthropology and Ethnography (Kunstkamera) RAS, 199034 St. Petersburg, Russia.

$30 \quad{ }^{21}$ Anuchin Research Institute and Museum of Anthropology, Lomonosov Moscow State University, Moscow, Russia.

${ }^{22}$ Sterlitamak Museum of Local History, Sterlitamak, Russia.

${ }^{23}$ Institute of Ethnology and Anthropology, Russian Academy of Sciences, Moscow, Russia.

${ }^{24}$ Samara State University of Social Sciences and Education, Samara, Russia.

\footnotetext{
${ }^{25}$ Institute of Archaeology named after A. Kh. Khalikov, Tatarstan Academy of Sciences, Kazan, Russia.
}

${ }^{26}$ Samara Museum for Historical and Regional Studies named after P.V. Alabin, Samara, Russia.

${ }^{27}$ Department of Prehistory and Archaeology, Faculty of Philosophy and Letters, University of Valladolid, Spain.

${ }^{28}$ Department of Prehistory and Archaeology, National Distance Education University (UNED), Madrid, Spain. 
${ }^{29}$ Private Technical Archaeologist.

${ }^{30}$ Department of Prehistory and Archaeology, Faculty of Philosophy and Letters, Autonomous University of Madrid, Spain.

${ }^{31}$ Technical Archaeologist, Government of Aragón, Spain.

$5 \quad{ }^{32}$ Thuringian State Office for Heritage Management and Archaeology, Humboldtstraße 11, 99423 Weimar, Germany.

${ }^{33}$ University Medical School Göttingen, Institute of Anatomy and Cell Biology, Kreuzbergring 36, 37075

Göttingen, Germany.

${ }^{34}$ Department of Archaeology, Durham University, South Road, Durham. DH1 3LE. UK.

$10 \quad{ }^{35}$ INRAP, ARAR UMR 5138, Maison de l’Orient et de la Méditerranée, Lyon, France.

${ }^{36}$ State Historical Museum, Moscow, Red Square 1, Russian Federation.

${ }^{37}$ Nasledie Cultural Heritage Unit, 355006 Stavropol, Russia.

${ }^{38}$ Department of Anthropology, The National Museum, Prague, Czech Republic.

${ }^{39}$ Institute of Archaeology of the Czech Academy of Sciences, Prague, Czech Republic.

$15{ }^{40}$ The City of Prague Museum, Prague, Czech Republic.

${ }^{41}$ Oxford Archaeology South, Janus House, Osney Mead, Oxford, OX2 0ES, UK.

${ }^{42}$ Oxford Archaeology East, 15 Trafalgar Way, Bar Hill, Cambridge, CB23 8SQ, UK.

${ }^{43}$ Forensic Medicine Unit, National Institute of Health and Welfare, Finland.

${ }^{44}$ Department of Anthropology, University of Winnipeg, Winnipeg, MB, Canada.

$20 \quad{ }^{45}$ Grupo de Investigación y Desarrollo, Dirección Provincial de Cultura, Matanzas, Cuba.

${ }^{46}$ Universidad de Matanzas, Matanzas, Cuba.

${ }^{47}$ Molecular Genetics Laboratory, Escuela Nacional de Antropología e Historia (ENAH), Mexico City, Mexico.

${ }^{48}$ Immunogenetics Unit, Técnicas Genéticas Aplicadas a la Clínica (TGAC), Mexico City, Mexico.

${ }^{49}$ Department of Archaeology, Classics and Egyptology, University of Liverpool, 8-14 Abercromby Square, 25 Liverpool, L69 7WZ, UK.

${ }^{50}$ Université Côte d'Azur, CNRS, CEPAM UMR 7264, Nice, France.

${ }^{51}$ Université de Strasbourg, CNRS, Archimède UMR 7044, Strasbourg, France.

${ }^{52}$ Department of Archaeology, Faculty of History, Lomonosov Moscow State University, Lomonosovsky pr. 27/4, 119192, Moscow, Russia.

$30 \quad{ }^{53}$ Institute of Archaeology, Russian Academy of Sciences, Dm. Uljanova str., 19, Moscow 117292, Russia. ${ }^{54}$ Department of Anthropology, University of South Florida, Tampa, FL, USA.

${ }^{55}$ Department of Anthropology, University of North Carolina at Charlotte, Charlotte, NC, USA.

${ }^{56}$ Istituto di Ricerca Genetica e Biomedica - CNR, Monserrato, Italy.

${ }^{57}$ Private contractor, Cagliari, Sardinia, Italy.

$35 \quad{ }^{58}$ Koç University, Research Center for Anatolian Civilizations, Istanbul 34433, Turkey.

${ }^{59}$ Institute for Research in Archaeology and Historical Heritage (INAPH); University of Alicante, 03690, Alicante, Spain.

${ }^{60}$ Departamento de Biotecnología, Facultad de Ciencias, Universidad de Alicante, 03690, Alicante, Spain.

${ }^{61}$ Bioarchaeology Service, Museum of the Civilizations, Rome, Italy. 
${ }^{62}$ Dipartimento Asia Africa e Mediterraneo, Università di Napoli L’Orientale, Napoli, Italy.

${ }^{63}$ Sedgeford Historical and Archaeological Research Project, Old Village Hall, Sedgeford, Hunstanton PE36 5LS, UK.

${ }^{64}$ Melbourne Dental School, The University of Melbourne, Victoria 3010 Australia.

${ }^{65}$ Cranfield Forensic Institute, Cranfield Defence and Security, Cranfield University, College Road, Cranfield, MK43 0AL, UK.

${ }^{66}$ Department of Veterinary Medicine, University of Cambridge, Cambridge CB3 0ES, UK.

${ }^{67}$ Astrakhan State University, Astrakhan, Russia.

${ }^{68}$ SNSB, State Collection for Anthropology and Palaeoanatomy, Karolinenplatz 2a, 80333 Munich, Germany.

${ }^{69}$ Department of Anthropology, Yale University, New Haven, CT 06511, USA.

${ }^{70}$ National Museum of Antiquities, Papengracht 30, P.O. Box 11114, 2301 EC Leiden, The Netherlands.

${ }^{71}$ Institute of History, Archaeology and Ethnography, Dushanbe, Tajikistan.

${ }^{72}$ Freie Universität Berlin, Einstein Center Chronoi, Otto-von-Simson-Str. 7, 14195 Berlin, Germany.

${ }^{73}$ Cronos S.C. Arqueología y Patrimonio, Burgos, Spain.

$15 \quad{ }^{74}$ Regional Historical Museum Varna, Varna, BG-9000, Maria Luiza Blvd. 41, Bulgaria.

${ }^{75}$ Institute for Caucasus Archaeology, Ul. Katkhanova 30, 361401 Nalchik, Republic Kabardino-Balkaria, Russia.

${ }^{76}$ Azov History, Archaeology and Palaeontology Museum-Reserve, Moskovskaya Street 38/40, Azov 346780, Russia.

$20 \quad{ }^{77}$ Museo de Sitio Pucllana, Calle General Borgoño crd. 8 s/n Miraflores 18 Lima, Peru.

${ }^{78}$ Australian Centre for Ancient DNA, School of Biological Sciences and The Environment Institute, Adelaide University, Adelaide, SA 5005, Australia.

${ }^{79}$ Centre of Excellence for Australian Biodiversity and Heritage (CABAH), University of Adelaide, Adelaide, SA 5005, Australia.

$25 \quad{ }^{80}$ National Centre for Indigenous Genomics, Australian National University, Canberra, ACT 0200, Australia.

${ }^{81}$ University Medical School Göttingen, Institute of Anatomy and Embryology, Kreuzbergring 36, 37075 Göttingen, Germany.

${ }^{82}$ Institute for Prehistory, Early History and Medieval Archaeology, University of Tübingen, 72070 Tübingen, Germany.

$30 \quad{ }^{83}$ State Office for Cultural Heritage Baden-Württemberg, Stromeyersdorfstraße 3, 78467 Konstanz, Germany.

${ }^{84}$ ArchaeoZoology in Siberia and Central Asia - ZooSCAn, CNRS - IAET SB RAS International Research Laboratory, IRL 2013, Novosibirsk, Russia.

${ }^{85}$ Department of Human Genetics, Leiden University Medical Center, Leiden, 2333 ZC, The Netherlands.

${ }^{86}$ Royal Belgian Institute of Natural Sciences, Brussels, Belgium.

$35 \quad{ }^{87}$ Center for Archaeological Sciences, University of Leuven, Belgium.

${ }^{88}$ Dienst Archeologie - Stad Mechelen, Belgium.

${ }^{89}$ UCSC Paleogenomics Lab, Department of Anthropology, University of California at Santa Cruz, Santa Cruz, CA 95064, USA.

${ }^{90}$ UCSC Genomics Institute, University of California at Santa Cruz, Santa Cruz, CA 95064, USA.

$40 \quad{ }^{91}$ Department of Anthropology, Vanderbilt University, VU Station B 356050, Nashville, TN 37235, USA. 
${ }^{92}$ Department of Physical Anthropology, Institute of Forensic Medicine, University of Bern, Bern, Switzerland.

${ }^{93}$ Applied Archaeology School of Science, Institute of Technology Sligo, Ireland.

${ }^{94}$ School of Historical and Philosophical Studies, The University of Melbourne, Victoria 3010, Australia.

${ }^{95}$ Institute of Prehistoric and Historical Archaeology, University of Vienna, Austria.

$5 \quad{ }^{96}$ Department of Archaeology, Hatay Mustafa Kemal University, Alahan-Antakya, Hatay 31060, Turkey.

${ }^{97}$ Institute for the Study of the Ancient World (ISAW), New York University, New York, NY 10028, USA.

${ }^{98}$ Territorial Service of Culture and Tourism from Valladolid, Castilla y León Regional Government, C/ San Lorenzo, 5, 47001, Valladolid, Spain.

${ }^{99}$ Department of History, Geography and Comunication, University of Burgos, Paseo de Comendadores, s/n

1009001 Burgos (Burgos), Spain.

${ }^{100}$ Dipartimento di Scienze Biomediche, Università di Sassari, Sassari, Italy.

${ }^{101}$ Área de Prehistoria, P3A DGA Research Group, IPH, University of Zaragoza, C/ Pedro Cerbuna 12, 50009,

Zaragoza, Spain.

${ }^{102}$ Department of Anthropology, Michigan State University, East Lansing, MI 48824, USA.

$15{ }^{103}$ Osteology Laboratory, Post Graduate Studies Division, Escuela Nacional de Antropología e Historia (ENAH), Mexico City, Mexico.

${ }^{104}$ Caribbean Research Institute, Univeristy of Winnipeg, Winnipeg, MB, Canada.

${ }^{105}$ DFG Center for Advanced Studies 'Words, Bones, Genes, Tools', University of Tübingen, Tübingen, Germany.

$20 \quad{ }^{106}$ South Tyrol Provincial Heritage Service.

${ }^{107}$ Grupo de Investigación en Prehistoria IT-1223-19 (UPV-EHU)/IKERBASQUE-Basque Foundation for Science, Vitoria, Spain.

${ }^{108}$ Departament de Prehistòria, Arqueologia i Història Antiga, Universitat de València, València, Spain.

${ }^{109}$ Department of Geological Sciences, University of Cape Town, Cape Town, South Africa.

$25 \quad{ }^{110}$ Human_G laboratory, Department of Anthropology, Hacettepe University, Ankara 06800, Turkey.

${ }^{111}$ The Cultural Heritage Foundation, 72212 Västerås, Sweden.

${ }^{112}$ National Archaeological Institute with Museum at the Bulgarian Academy of Sciences, Sofia, 1000, 2 Saborna str., Bulgaria.

${ }^{113}$ School of Natural Sciences, University of Central Lancashire, Preston, UK.

$30 \quad{ }^{114}$ Department of Biosciences, University of Helsinki, Viikinkaari 9, 00014 Helsinki, Finland.

${ }^{115}$ Department of Biology, University of Turku, Vesilinnantie 5, 20500 Turku, Finland.

${ }^{116}$ Institute of archaeology named after A.Kh. Margulan, 050010, Dostyk ave., 44, Almaty, Kazakhstan

${ }^{117}$ Branch of Institute of Archaeology named after A.Kh. Margulan, 010011, Republic ave., 24, of. 511, NurSultan, Kazakhstan.

$35{ }^{118}$ State Historical and Cultural Museum-Reserve "Berel", 070906, set. Zhambyl, Katon-Karagay district, East Kazakhstan region, Kazakhstan.

${ }^{119}$ Institut für Vor- und Frühgeschichtliche Archäologie und Provinzialrömische Archäologie, LudwigMaximilians-Universität München, 80539 Munich, Germany.

40 Denmark. 
${ }^{121}$ Department of Human Evolution, Max Planck Institute for Evolutionary Anthropology (MPI-EVA), Leipzig, Deutscher Platz 6, D-04103, Germany.

${ }^{122}$ Department of Cultures, Archaeology, University of Helsinki, Unioninkatu 38 F, 00170 Helsinki, Finland.

${ }^{123}$ Research Centre for Medical Genetics, Moscow, Russia.

$5 \quad{ }^{124}$ Biobank of North Eurasia, Moscow, Russia.

${ }^{125}$ Vavilov Institute of General Genetics, Moscow, Russia.

${ }^{126}$ Eurasia Department, German Archaeological Institute, Berlin, Germany.

${ }^{127}$ Danube Private University, Center of Natural and Cultural Human History, Steiner Landstrasse 124, A - 3500 Krems-Stein, Austria.

$10{ }^{128}$ Integrative Prehistory and Archaeological Science, Spalenring 145, CH-4055 Basel, Switzerland.

${ }^{129}$ Department of Biomedical Engineering (DBE), Universitätsspital Basel (HFZ), Gewerbestrasse 14-16, Labor 14.03.021-023, CH-4123 Allschwil, Switzerland.

${ }^{130}$ Department of Anthropology, Harvard University, 11 Divinity Ave., Cambridge, MA 02138 USA.

${ }^{131}$ School of Biological Sciences, The University of Adelaide, Adelaide, SA, 5005, Australia.

$15{ }^{132}$ European Virus Bioinformatics Center (EVBC), Jena, Germany.

*Corresponding author. Email: kocher@shh.mpg.de; krause@shh.mpg.de;

kuehnert@shh.mpg.de 


\begin{abstract}
Hepatitis B virus (HBV) has been infecting humans for millennia and remains a global health problem, but its past diversity and dispersal routes are largely unknown. We generated HBV genomic data from 137 Eurasians and Native Americans dated between $\sim 10,500$ and $\sim 400$ years

5 ago. We date the most recent common ancestor of all HBV lineages to between $\sim 20,000$ and 12,000 years ago, with the virus present in European and South Americans during the early Holocene. Following the European Neolithic transition, Mesolithic HBV strains were replaced by a lineage likely disseminated by early farmers that prevailed throughout western Eurasia for $\sim 4,000$ years, declining around the end of the 2 nd millennium BCE. The only remnant of this

10 prehistoric HBV diversity is the rare genotype $\mathrm{G}$, which appears to have re-emerged during the HIV pandemic.
\end{abstract}

\title{
One-Sentence Summary:
}

Uncovering 10,000 years of hepatitis B virus evolution by analyzing genomes from ancient Eurasians and Native Americans 


\section{Main Text:}

The World Health Organization (WHO) estimates that in 2015, 257 million people were living with chronic hepatitis B virus (HBV) infection, which causes close to one million deaths each year (1). HBV is transmitted through contact with bodily fluids, mainly in sexual and perinatal contexts (2), and has no known environmental or animal reservoir. Its spread is therefore tightly linked to the dispersal of humans, whose past population dynamics and migrations have likely shaped the genetic diversity of this partially double-stranded DNA virus, which is currently classified into nine genotypes associated with characteristic ethno-geographic ranges $[(3,4)$; Fig. 1]. However, the temporal and geographic context of HBV origins in humans, as well as its major routes of dissemination in the past, remain widely debated (5-10). Recent studies have retrieved HBV DNA from archaeological human remains (11-16), providing new avenues to address questions about HBV evolution and phylogeographic history. In particular, these studies revealed the presence of HBV in Europe as early as the Neolithic and ancient HBV lineages that are now seemingly extinct. Ancient DNA data permits molecular clock

15 calibration, and the time to the most recent common ancestor (tMRCA) of all known HBV lineages has been dated to between $\sim 21$ and $\sim 9$ thousand years ago (ka) (14). However, the extent of the past diversity of this virus remains generally unknown as only 19 ancient HBV genomes with a limited temporal and geographic distribution have been reconstructed to date.

\section{The MRCA of all known HBV lineages}

20 Here, we report genomic evidence of HBV in the skeletal remains of 137 individuals from Eurasia and the Americas dated to between $\sim 10,500$ and 400 years ago (Figs. 1, S1; Data S1). Despite advances in molecular virology and numerous sequences from present-day HBV 
genomes, assessing the phylogenetic relationships among HBV genotypes has proven challenging $(7,17-20)$, and doubts have been cast about its evolutionary rate and molecular clock-like behavior $(9,16,21)$. Nevertheless, most HBV phylogenetic reconstructions have recovered a topology in which $\mathrm{HBV}$ genotypes typically found in Native Americans $(\mathrm{F}$ and $\mathrm{H})$ represent a sister clade to the rest of worldwide HBV diversity (18) (which we refer to as the Eurasian branch). This topology was supported by a study incorporating 12 ancient HBV genomes (14), and is retrieved here (Figs. 2, S2, S3). In particular, the monophyly of the American HBV branch, comprising all ancient genomes from the Americas dating back to as early as $\sim 9$ ka from the Cuncaicha rock shelter in the Andean highlands (CUN002), was highly supported. On the other hand, deep nodes within the Eurasian branch were not well resolved, pointing to plausible alternative topologies in which some of the earliest Eurasian lineages would have diverged before the American branch [see (22); Figs. S4, S5]. Our results confirm that HBV genomic data do exhibit a clear temporal structure when incorporating samples spanning several thousand years (fig. S3). Using the best-fitting uncorrelated relaxed clock

15 model, we estimate the tMRCA of HBV, corresponding to the divergence of American and Eurasian HBV branches, between $\sim 16$ and $\sim 12$ ka [95\% Highest Posterior Density (HPD); table S1], within the range of previous findings (14). This suggests that contacts between ancestral Eurasians and First Americans occurred until at least shortly before the Bølling-Allerød interstadial ( $\sim 15-13 \mathrm{ka})$, a period of warming corresponding to widespread human expansion 20 in North America $(23,24)$. However, studies of ancient human genomes indicate that the ancestors of the First Americans likely began diverging from their closest Eurasian relatives between $\sim 25$ and $18 \mathrm{ka}$, possibly reflecting an extended isolation in a Beringian refugium during the Last Glacial Maximum, before dispersing into and across the Americas (25-27). The 
use of a time-dependent rate model yielded an estimate of $\sim 20-17$ ka for the HBV tMRCA (95\% HPD), which was more consistent in this regard. This suggests that not accounting for the time-dependency of the evolutionary rate may have led to an underestimation of deep divergence times. However, model selection favored the use of a relaxed clock over a TDR model (log BF: 405) (22). Taken together, these results point to a scenario in which the MRCA of all HBV strains examined to date existed around the end of the Pleistocene and gave rise to one or several lineages that spread across Eurasia and eventually reached Africa and Oceania, and to another lineage that spread into the Americas with early settlers of this continent.

Our findings challenge the view that current HBV diversity reflects early human dispersals out of Africa. This model is supported, in particular, by the exclusive association of HBV subgenotype C4 with the Aboriginal people of Australia, suggesting that this subgenotype may have been carried by the first settlers of Australia at least $\sim 50 \mathrm{ka}(5,20)$. Instead, in accordance with previous findings (14), our results indicate that all known modern and ancient HBV strains descend from a lineage that began to diversify at a more recent stage of human history, and that 15 subgenotype C4 was introduced in the Australian continent after $\sim 4.5 \mathrm{ka}$ (Fig. 2). Nevertheless, the age of the observed MRCA only represents a lower limit for the earliest presence of HBV in humans. Whether the latter has been preceded by long coevolution, a recent spillover from another animal species, or any intermediate scenario, remains an open question. Other viruses from the Hepadnaviridae family have been recovered from a wide range of vertebrates, but none of them appear to represent an ancestral zoonotic source for the human HBV $(8)$. 


\section{HBV circulated widely in western Eurasia as early as $10 \mathrm{ka}$}

The retrieval of HBV genomes from around $10 \mathrm{ka}$ in different parts of Europe and Anatolia, indicate that the virus was widespread in western Eurasia at that time (Figs. 1, S1). The oldest HBV strains recovered in Europe form two distinct clades (Figs. 2, S2; table S2): one that was

5 found in three hunter-gatherers (HG) from northwestern Russia, Belgium and Doggerland (Mesolithic 1), and another that was found in a HG from western Russia (Mesolithic 2). These two lineages are placed within the Eurasian branch as sister groups to the modern strains found in non-human primates (NHP) from Southeast Asia and Africa, respectively. The position of NHP HBV lineages within human HBV diversity has been observed in most previous

10 phylogenetic reconstructions and is thought to reflect spillover events from humans to NHPs $(7,22,28)$. The HBV genome reconstructed from an early Anatolian farmer forms a separate lineage recovered at a phylogenetic position intermediate to the two European Mesolithic clades. Between $\sim 9$ and $7.5 \mathrm{ka}, \mathrm{HBV}$ strains found in HGs from Karelia (northwestern Russia), Sweden, Luxembourg and Sicily all belonged to the Mesolithic 2 clade. Thus, although our

15 data do not allow detailed phylogeographic inference, they suggest that, during the early Holocene, HBV strains could spread over large parts of western Eurasia within a few thousand years. This is consistent with evidence of genetic connections between Europe and the Near East that predate the Neolithic transition $(29,30)$, and with the observed genetic cline from Western to Eastern HGs (31). Our results further highlight that Mesolithic populations likely

20 formed a network through which pathogens could spread.

It has been suggested that most human-adapted pathogens emerged after the Neolithic transition in association with sedentary lifestyles, increased contact with domesticated animals, and higher population densities, a phenomenon sometimes referred to as the "first epidemiological 
transition" (32-34). Our finding of widespread HBV in HG populations indicates that HBV was present prior to the advent of agriculture and animal husbandry in different parts of the world. Today, HBV rarely causes lethal fulminant hepatitis, but rather asymptomatic infections that may evolve into chronic forms, sometimes developing into liver complications and possible liver failure after decades of infection $(1,2)$. Although it is difficult to extrapolate from presentday medical studies what the clinical impact of a pathogen would have been in the past, given different diets, disease burdens, and life expectancies, the virus has likely exhibited similar pathophysiological features. Consequently, our findings are consistent with the view that, although small HG communities could not sustain highly epidemic "crowd" diseases, they could maintain chronic infectious agents $(35,36)$.

\section{A replacement of HBV diversity occurred with the Neolithic transition in Europe}

Our data show that HBV remained widespread in Europe after the Neolithic transition (8-7 ka), with numerous strains recovered from early European farmers (EEF) across the continent (Figs. 3, S1; Data S1). Remarkably, all of these strains belong to a single HBV lineage that does not

15 descend from previously observed Mesolithic strains (Figs. 2, 3, S2). We refer to this HBV lineage as the Western-Eurasian Neolithic-to-Bronze-Age (WENBA) lineage. This transition is also observable at a micro-scale in Grotta dell'Uzzo (Sicily), where HBV strains recovered from Neolithic individuals are unrelated to a Late Mesolithic strain identified at the same site (figs. S1, S2). This suggests that the HBV strains observed in EEFs were not acquired from

20 local HGs in different areas, but were rather disseminated by EEFs themselves. While EEFs ultimately derived from early agricultural populations in the Near East $(37,38)$, the strain we retrieved from an Anatolian farmer dated to $\sim 10$ ka was not ancestral to the WENBA lineage (Fig. 2). Therefore, even if EEFs were indeed key in disseminating WENBA strains, whether 
this lineage originated in Near Eastern centers of early agriculture or in another location along EEF's expansion routes remains to be determined. Furthermore, given the current sample availability for this period, a scenario in which the WENBA lineage would have originated and disseminated among European HGs shortly before the Neolithic transition cannot be completely excluded.

Later, we find WENBA HBV strains in two HGs from transitional Neolithic contexts in western Russia dated to 7.2 and $\sim 6.4 \mathrm{ka}$ (JAZ001 and MUR007), as well as on both sides of the Greater Caucasus Mountain range and in Anatolia as early as $\sim 5.6 \mathrm{ka}$ (fig. S1). In general, phylogenetic relationships among HBV sublineages within the WENBA clade do not exhibit a strong geographical structure (fig. S2), nor do they seem to reflect the material culture or genetic profile of the individuals in which they were found (fig. S6). Furthermore, our phylodynamic reconstruction indicates that, after an initial growth phase, the transmission of WENBA HBV reached an equilibrium from $\sim 7.5$ to $\sim 3.5 \mathrm{ka}$ (fig. S7). Overall, this suggests that HBV strains disseminated by EEFs quickly spread throughout much of western Eurasia beyond the limits of 15 the European agricultural expansion, where they became endemic and continued to circulate widely across different populations, for several thousand years. In particular, we do not observe significant changes in the HBV genetic landscape associated with the expansion of stepperelated ancestry that dramatically altered the genetic profile of Europeans from $\sim 5$ ka onward (37) (Figs. 2, S2; Data S1). Sexual and perinatal transmission have likely always been the major mechanisms of HBV infection in humans, but cultural practices involving contact with blood [e.g., tattooing (39)] or non-sexual violent interactions (40) could also have played a role in the spread of the virus in the past. In general, our findings attest to a degree of interconnectivity 
among prehistoric populations of different origins, subsistence modes, and cultures that allowed for the dissemination of directly-transmitted pathogens.

\section{The 2nd millennium BCE collapse of WENBA HBV}

Following the Early Neolithic (8-7 ka), the WENBA HBV lineage prevailed in most parts of western Eurasia for more than 4,000 years (Fig. 3). However, the latest occurrence of a WENBA strain in our dataset is dated to $\sim 3.3 \mathrm{ka}$, after which this lineage is no longer observed (figs. S1, S2). In contrast, genotype A, which we first observe at the eastern edge of Europe and in the Near East between $\sim 5$ and $\sim 3.5 \mathrm{ka}$, still appears after $\sim 2.5 \mathrm{ka}$, by which time it had reached the Carpathian Basin in central Europe. Around the same date, we first observe genotype D in two individuals from the Italian Alps, as well as in various locations in the western steppe, before prevailing in large parts of Europe during the Medieval period. Thus, it seems that as most WENBA HBV lineages disappeared by the end of the 2nd millennium BCE, genotypes A and D subsequently spread from eastern reservoirs to eventually reach western regions that had previously only harbored WENBA strains (22).

15 The second half of the 2nd millennium BCE bears witness to major cultural shifts in the archaeological record in western Eurasia, including the sudden disappearance of tell settlements in the Carpathian Basin (41), the expansion of the Urnfield culture and the increase of military conflicts in large parts of Europe (42-45), the breakdown of the Terramare culture in northern Italy (46), and the so-called Late Bronze Age collapse of most state societies in the eastern Mediterranean region and Near East $(47,48)$. Some of these societal transformations could have been triggered by underlying phenomena such as climatic events (49) or the spread of epidemic diseases (50), and were likely associated with significant shifts in population 
densities, trans-regional networks, and modes and scales of human mobility. The observed decline of WENBA HBV diversity, as well as our phylodynamic reconstruction (fig. S7), further point to important changes in epidemiological dynamics over large parts of western Eurasia during this period. However, while our data suggests that new lineages disseminated across Europe only later on, the lack of observations around 3 ka (Fig. 3) could reflect sampling biases related to the widespread adoption of cremation practices around that time (42-44), rather than a decrease of HBV prevalence. Searching for the virus in a large number of systematically dated samples across this period could help to better characterize the process that ultimately led to the renewal of western Eurasian HBV diversity after the end of the 2nd millennium BCE.

\section{Recent re-emergence of the WENBA HBV lineage}

The majority of HBV strains circulating in western Eurasia today belong to genotypes A and $\mathrm{D}(3,4)$, thus only reflecting a relatively recent part of the phylogeographic history of this virus. However, our results show that despite the seemingly complete disappearance of WENBA

15 HBV strains around the end of the 2nd millennium BCE, one lineage descending from this clade has, in fact, persisted to the present. The latter gave rise to a group of modern strains classified as genotype G (Figs. 2, S2), a rare, recently described genotype for which the biology is poorly understood (51). First discovered in patients from France and the United States, genotype $\mathrm{G}$ was later found in other parts of Europe, the Americas, and in Asia, making its

20 geographic origin unclear (52). Despite its wide distribution, genotype G exhibits remarkably low genetic diversity (53), suggesting a recent re-emergence after thousands of years of lowlevel persistence. Furthermore, genotype G has mostly been found in HIV-positive patients, and phylodynamic patterns have pointed to a sharp increase of its dissemination co-occurring 
with the HIV pandemic, possibly associated with highly sexually active groups and injection drug users (52).

Genotype G has sometimes been referred to as "aberrant" due to its unique genomic features: a 36-nt insertion near the 5' end of the core gene and two nonsense mutations in the pre-core region $(51,54)$. These changes inhibit production of the immunotolerogen e antigen $(\mathrm{HBe} A g)$, which appears essential for the establishment of a persistent HBV infection, and alter the structure of the HBV core protein, which may impair packaging and replication of the viral genetic material $(54,55)$. This likely explains why, in the vast majority of cases, genotype $\mathrm{G}$ occurs in co-infections with other HBV genotypes, which can provide the HBeAg and core protein production functions lacking in genotype G (54-56). We identified similar insertions and stop codons in 14 ancient $\mathrm{HBV}$ genomes ranging in age between $\sim 7$ and $3.5 \mathrm{ka}$, which form the WENBA subclade from which genotype G descends (fig. S8). Additionally, most of these ancient genomes were found in individuals showing signs of infections with several HBV variants [fig. S8; Data S2; (22)]. In fact, cases of mixed infection were exclusively found in 15 individuals carrying WENBA HBV strains, among which they were very frequent $(22 / 83$ individuals, likely underestimating the true frequency). In all cases, both major and minor strains appeared to belong to the WENBA lineage, and sequencing data were partially supporting a 4 40-bp insertion at the 5' end of the core gene (table S3; Data S1).

Therefore, while genotype $\mathrm{G}$ is considered rare today, it seems that the co-transmission of its ancestral form together with another HBeAg+ WENBA strain was a common epidemiological feature of HBV between $\sim 7.5$ and $3.5 \mathrm{ka}$. On the other hand, it may appear surprising that this functionally-limited variant specifically persisted until today while the rest of the WENBA HBV diversity seemingly went extinct. Virologic studies indicate that genotype G tends to 
outcompete $\mathrm{HBeAg}$-producing strains during late $\mathrm{HBV}$ infection stages following anti-HBeAg seroconversion (56-58). It is tempting to speculate a link between these short-term selection patterns and the survival of this lineage over thousands of years, but the latter might also be related to less deterministic factors. One of the closest Bronze Age ancestors of genotype G was recovered at the archaeological site of Shagara in the eastern European forest zone (SGR003; figs. S1, S2), a location where the nowadays-widespread genotype A was already circulating (SGR004). Of note, genotype A is the most common genotype found with genotype $\mathrm{G}$ in mixed infections today $(55,57)$. The discovery of ancestral forms of both genotypes at the same archaeological site, albeit from different individuals and time periods, may indicate that this viral association had already formed during prehistory in eastern Europe.

\section{Conclusions}

This study demonstrates the value of large-scale paleogenomic analyses for studying the phylogeographic history of HBV. DNA-enrichment allowed us to reconstruct large proportions of over one hundred ancient HBV genomes from a variety of skeletal tissues, opening important

15 possibilities for future paleovirologic studies. We show that HBV was already widely present in humans during the early Holocene, and that its phylogeographic history reflects several wellknown human migrations and demographic events, including the expansion of First American populations in the Americas and the Neolithic transition in Europe, but not others, such as later Bronze Age steppe ancestry expansions. Furthermore, our results reveal patterns that were not 20 expected on the basis of human genetic and archaeological data alone, such as the near complete renewal of western Eurasian HBV diversity around the end of the 2nd millennium BCE. These findings highlight that the reconstruction of ancient viral diversity has great potential to contribute to our understanding of human history. 


\section{References and Notes}

1. World Health Organization, Global hepatitis report, 2017

2. D. Lavanchy, M. Kane, in Hepatitis B Virus in Human Diseases, Y.-F. Liaw, F. Zoulim, Eds. (Springer International Publishing, Cham, 2016), Molecular and Translational Medicine, pp. 187-203.

3. A. Kramvis, Genotypes and Genetic Variability of Hepatitis B Virus. Intervirology. 57, 141-150 (2014).

4. S. Velkov, J. J. Ott, U. Protzer, T. Michler, The Global Hepatitis B Virus Genotype Distribution Approximated from Available Genotyping Data. Genes. 9, 495 (2018).

5. M. Littlejohn, S. Locarnini, L. Yuen, Origins and Evolution of Hepatitis B Virus and Hepatitis D Virus. Cold Spring Harb Perspect Med. 6, a021360 (2016).

6. S. Locarnini, M. Littlejohn, M. N. Aziz, L. Yuen, Possible origins and evolution of the hepatitis B virus (HBV). Seminars in Cancer Biology. 23, 561-575 (2013).

7. D. Paraskevis et al., Dating the origin and dispersal of hepatitis B virus infection in humans and primates. Hepatology. 57, 908-916 (2013).

8. A. Rasche, A.-L. Sander, V. M. Corman, J. F. Drexler, Evolutionary biology of human hepatitis viruses. Journal of Hepatology. 70, 501-520 (2019).

9. P. Simmonds, Reconstructing the origins of human hepatitis viruses. Philosophical Transactions of the Royal Society of London. Series B: Biological Sciences. 356, 1013-1026 (2001).

10. G. Zehender et al., Enigmatic origin of hepatitis B virus: An ancient travelling companion or a recent encounter? World $J$ Gastroenterol. 20, 7622-7634 (2014).

11. G. K. Bar-Gal et al., Tracing hepatitis B virus to the 16th century in a Korean mummy. Hepatology. 56, 1671-1680 (2012).

12. R. Barquera et al., Origin and Health Status of First-Generation Africans from Early Colonial Mexico. Current Biology. 30, 20782091.e11 (2020).

13. B. Krause-Kyora et al., Neolithic and medieval virus genomes reveal complex evolution of hepatitis B. eLife. 7, e36666 (2018).

14. B. Mühlemann et al., Ancient hepatitis B viruses from the Bronze Age to the Medieval period. Nature. 557, 418 (2018).

15. J. Neukamm et al., 2000-year-old pathogen genomes reconstructed from metagenomic analysis of Egyptian mummified individuals. BMC Biology. 18, 108 (2020).

16. Z. P. Ross et al., The paradox of HBV evolution as revealed from a 16th century mummy. PLOS Pathogens. 14, e1006750 (2018).

17. P. L. Bollyky, E. C. Holmes, Reconstructing the Complex Evolutionary History of Hepatitis B Virus. J Mol Evol. 49, 130-141 (1999).

18. B. A. Godoy, J. R. R. Pinho, N. J. R. Fagundes, Hepatitis B Virus: Alternative phylogenetic hypotheses and its impact on molecular evolution inferences. Virus Research. 276, 197776 (2020).

19. D. Paraskevis et al., Dating the origin of hepatitis B virus reveals higher substitution rate and adaptation on the branch leading to $\mathrm{F} / \mathrm{H}$ genotypes. Molecular Phylogenetics and Evolution. 93, 44-54 (2015).

20. L. K. W. Yuen et al., Tracing Ancient Human Migrations into Sahul Using Hepatitis B Virus Genomes. Mol Biol Evol. 36, 942-954 (2019).

21. R. Bouckaert, M. V. Alvarado-Mora, J. R. Rebello Pinho, Evolutionary rates and HBV: Issues of rate estimation with Bayesian molecular methods. Antivir Ther. 18, 497-503 (2013).

22. See supplementary materials.

23. D. Palacios et al., The deglaciation of the Americas during the Last Glacial Termination. Earth-Science Reviews. 203, 103113 (2020).

24. M. R. Waters, Late Pleistocene exploration and settlement of the Americas by modern humans. Science. 365, eaat5447 (2019).

25. B. Llamas et al., Ancient mitochondrial DNA provides high-resolution time scale of the peopling of the Americas. Science Advances. 2, e1501385 (2016).

26. J. V. Moreno-Mayar et al., Terminal Pleistocene Alaskan genome reveals first founding population of Native Americans. Nature. 553, 203-207 (2018).

27. M. Raghavan et al., Genomic evidence for the Pleistocene and recent population history of Native Americans. Science. 349, aab3884 (2015).

28. B. F. Souza et al., A novel hepatitis B virus species discovered in capuchin monkeys sheds new light on the evolution of primate hepadnaviruses. Journal of Hepatology. 68, 1114-1122 (2018). 
29. M. Feldman et al., Late Pleistocene human genome suggests a local origin for the first farmers of central Anatolia. Nature Communications. 10, 1218 (2019).

30. Q. Fu et al., The genetic history of Ice Age Europe. Nature. 534, 200-205 (2016).

31. I. Mathieson et al., The genomic history of southeastern Europe. Nature. 555, 197-203 (2018).

32. R. Barrett, C. W. Kuzawa, T. McDade, G. J. Armelagos, Emerging and Re-Emerging Infectious Diseases: The Third Epidemiologic Transition. Annual Review of Anthropology. 27, 247-271 (1998).

33. J. Diamond, Evolution, consequences and future of plant and animal domestication. Nature. 418, 700-707 (2002).

34. F. M. Key et al., Emergence of human-adapted Salmonella enterica is linked to the Neolithization process. Nat Ecol Evol. 4, 324$333(2020)$

35. M. C. Inhorn, P. J. Brown, The Anthropology of Infectious Disease. Annual Review of Anthropology. 19, 89-117 (1990).

36. N. D. Wolfe, C. P. Dunavan, J. Diamond, Origins of major human infectious diseases. Nature. 447, 279-283 (2007).

37. W. Haak et al., Massive migration from the steppe was a source for Indo-European languages in Europe. Nature. 522, 207-211 (2015).

38. I. Lazaridis et al., Ancient human genomes suggest three ancestral populations for present-day Europeans. Nature. 513, 409-413 (2014).

39. A. Deter-Wolf, B. Robitaille, L. Krutak, S. Galliot, The world's oldest tattoos. Journal of Archaeological Science: Reports. 5, 19-24 (2016).

40. K. W. Alt et al., A massacre of early Neolithic farmers in the high Pyrenees at Els Trocs, Spain. Scientific Reports. 10, 2131 (2020).

41. F. Gogâltan, The Chronology of the Bronze Age Tell and Tell-like Settlements in the Carpathian Basin. Revisited after 15 Years. Studia Hercynia. 23, 198-214 (2019).

42. G. Capuzzo, J. A. Barceló, Cultural changes in the second millennium BC: A Bayesian examination of radiocarbon evidence from Switzerland and Catalonia. World Archaeology. 47, 622-641 (2015).

43. F. Falkenstein, in Ancestral Landscape. Burial mounds in the Copper and Bronze Ages (Central and Eastern Europe - Balkans Adriatic - Aegean, 4th-2nd millennium B.C.) Proceedings of the International Conference held in Udine, May 15th-18th 2008 (Maison de l'Orient et de la Méditerranée Jean Pouilloux, Lyon, 2012), Travaux de la Maison de l'Orient et de la Méditerranée. Série recherches archéologiques, pp. 329-340.

44. H. Fokkens, The genesis of urnfields: Economic crisis or ideological change? Antiquity. 71, 360-373 (1997).

45. S. Hansen, in Hillforts and Weaponry in the Early and Middle Bronze Age, S. Hansen, R. Krause, Eds. (Habelt, Bonn, 2019).

46. A. Cardarelli, in Scienze dell'Antichità (Edizioni Quasar, 2009), vol. 15, pp. 449-520.

47. E. H. Cline, 1177 B.C.: The Year Civilization Collapsed (Princeton University Press, 2015).

48. J. Driessen et al., An Archaeology of Forced Migration. Crisis-induced mobility and the Collapse of the 13th c. BCE Eastern Mediterranean (PLU, Louvain-la-Neuve, 2018).

49. D. Kaniewski, E. V. Campo, in 3.2 ka BP Megadrought and the Late Bronze Age Collapse, H. Weiss, Ed. (Oxford University Press, 2017).

50. P. Norrie, in A History of Disease in Ancient Times: More Lethal than War, P. Norrie, Ed. (Springer International Publishing, Cham, 2016), pp. 61-101.

51. L. Stuyver et al., A new genotype of hepatitis B virus: Complete genome and phylogenetic relatedness. Journal of General Virology, 81, 67-74 (2000).

52. J. M. Wolf, S. D. Carli, V. R. Z. B. Pereira, D. Simon, V. R. Lunge, Temporal evolution and global spread of hepatitis B virus genotype G. Journal of Viral Hepatitis. 28, 393-399 (2021).

53. M. Cornelissen et al., Widespread hepatitis B virus genotype G (HBV-G) infection during the early years of the HIV epidemic in the Netherlands among men who have sex with men. BMC Infect Dis. 16, 268 (2016).

54. K. Li et al., Critical Role of the 36-Nucleotide Insertion in Hepatitis B Virus Genotype G in Core Protein Expression, Genome Replication, and Virion Secretion. Journal of Virology. 81, 9202-9215 (2007).

45 55. T. Sakamoto et al., Mechanism of the dependence of hepatitis B virus genotype G on co-infection with other genotypes for viral replication. Journal of Viral Hepatitis. 20, e27-e36 (2013).

56. Y. Tanaka et al., Characteristics of hepatitis B virus genotype $\mathrm{G}$ coinfected with genotype $\mathrm{H}$ in chimeric mice carrying human hepatocytes. Virology. 376, 408-415 (2008). 
58. M. Sugiyama et al., Early dynamics of hepatitis B virus in chimeric mice carrying human hepatocytes monoinfected or coinfected with genotype G. Hepatology. 45, 929-937 (2007).

59. Å. J. Vågene et al., Salmonella enterica genomes from victims of a major sixteenth-century epidemic in Mexico. Nat Ecol Evol. 2 , $520-528$ (2018).

60. R. Hübler et al., HOPS: Automated detection and authentication of pathogen DNA in archaeological remains. Genome Biology. 20, 280 (2019)

61. Q. Fu et al., DNA analysis of an early modern human from Tianyuan Cave, China. PNAS. 110, 2223-2227 (2013).

62. M. Schubert, S. Lindgreen, L. Orlando, AdapterRemoval v2: Rapid adapter trimming, identification, and read merging. BMC Research Notes. 9, 88 (2016).

63. I. B. Schnell, K. Bohmann, M. T. P. Gilbert, Tag jumps illuminated - reducing sequence-to-sample misidentifications in metabarcoding studies. Molecular Ecology Resources. 15, 1289-1303 (2015).

64. P. Esling, F. Lejzerowicz, J. Pawlowski, Accurate multiplexing and filtering for high-throughput amplicon-sequencing. Nucleic Acids Research. 43, 2513-2524 (2015).

65. N. Dierckxsens, P. Mardulyn, G. Smits, NOVOPlasty: De novo assembly of organelle genomes from whole genome data. Nucleic Acids Res. 45, e18-e18 (2017).

66. A. Peltzer et al., EAGER: Efficient ancient genome reconstruction. Genome Biology. 17, 60 (2016).

67. M. A. DePristo et al., A framework for variation discovery and genotyping using next-generation DNA sequencing data. Nat Genet. 43, 491-498 (2011).

68. D. Bates, M. Mächler, B. Bolker, S. Walker, Fitting Linear Mixed-Effects Models Using lme4. Journal of Statistical Software. 67, $1-48(2015)$.

69. H. Delius, N. M. Gough, C. H. Cameron, K. Murray, Structure of the hepatitis B virus genome. Journal of Virology. 47, 337-343 (1983).

70. A. W. Briggs et al., Removal of deaminated cytosines and detection of in vivo methylation in ancient DNA. Nucleic Acids Res. 38, e87-e87 (2010)

71. H. Jónsson, A. Ginolhac, M. Schubert, P. L. F. Johnson, L. Orlando, mapDamage2.0: Fast approximate Bayesian estimates of ancient DNA damage parameters. Bioinformatics. 29, 1682-1684 (2013).

72. P. Barbera et al., EPA-ng: Massively Parallel Evolutionary Placement of Genetic Sequences. Systematic Biology. 68, 365-369 (2019).

73. K. Katoh, D. M. Standley, MAFFT multiple sequence alignment software version 7: Improvements in performance and usability. Molecular biology and evolution. 30, 772-780 (2013).

74. J. Castresana, Selection of conserved blocks from multiple alignments for their use in phylogenetic analysis. Molecular biology and evolution. 17, 540-552 (2000).

75. A. Stamatakis, RAxML Version 8: A tool for phylogenetic analysis and post-analysis of large phylogenies. Bioinformatics. 30, 13121313 (2014).

76. A. Rambaut, T. T. Lam, L. Max Carvalho, O. G. Pybus, Exploring the temporal structure of heterochronous sequences using TempEst (formerly Path-O-Gen). Virus Evol. 2, vew007 (2016).

77. S. Duchene et al., Bayesian Evaluation of Temporal Signal in Measurably Evolving Populations. Mol Biol Evol. 37, 3363-3379 (2020).

78. R. Bouckaert et al., BEAST 2: A Software Platform for Bayesian Evolutionary Analysis. PLoS Computational Biology. 10, e1003537 (2014).

79. N. Lartillot, H. Philippe, Computing Bayes Factors Using Thermodynamic Integration. Systematic Biology. 55, 195-207 (2006).

80. A. J. Drummond, A. Rambaut, B. Shapiro, O. G. Pybus, Bayesian Coalescent Inference of Past Population Dynamics from Molecular Sequences. Molecular Biology and Evolution. 22, 1185-1192 (2005).

81. T. Stadler, D. Kühnert, S. Bonhoeffer, A. J. Drummond, Birth-death skyline plot reveals temporal changes of epidemic spread in HIV and hepatitis C virus (HCV). PNAS. 110, 228-233 (2013).

45 82. A. J. Drummond, S. Y. W. Ho, M. J. Phillips, A. Rambaut, Relaxed Phylogenetics and Dating with Confidence. PLOS Biology. 4, e88 (2006).

83. J. Heled, R. R. Bouckaert, Looking for trees in the forest: Summary tree from posterior samples. BMC Evol Biol. 13, 221 (2013).

84. D. P. Martin, B. Murrell, M. Golden, A. Khoosal, B. Muhire, RDP4: Detection and analysis of recombination patterns in virus genomes. Virus Evol. 1, vev003 (2015).

85. S. Duchêne, E. C. Holmes, S. Y. W. Ho, Analyses of evolutionary dynamics in viruses are hindered by a time-dependent bias in rate estimates. Proceedings of the Royal Society B: Biological Sciences. 281, 20140732 (2014). 
86. M. A. Suchard et al., Bayesian phylogenetic and phylodynamic data integration using BEAST 1.10. Virus Evol. 4 (2018).

87. J. V. Membrebe, M. A. Suchard, A. Rambaut, G. Baele, P. Lemey, Bayesian Inference of Evolutionary Histories under TimeDependent Substitution Rates. Mol Biol Evol. 36, 1793-1803 (2019).

88. G. Baele et al., Improving the Accuracy of Demographic and Molecular Clock Model Comparison While Accommodating Phylogenetic Uncertainty. Molecular Biology and Evolution. 29, 2157-2167 (2012).

89. L. O. Magnius, H. Norder, Subtypes, Genotypes and Molecular Epidemiology of the Hepatitis B Virus as Reflected by Sequence Variability of the S-Gene. INT. 38, 24-34 (1995).

90. J. M. Wolf, S. De Carli, V. R. Z. B. Pereira, D. Simon, V. R. Lunge, Temporal evolution and global spread of hepatitis B virus genotype G. J Viral Hepat. 28, 393-399 (2021).

91. B. Mühlemann et al., Diverse variola virus (smallpox) strains were widespread in northern Europe in the Viking Age. Science. 369, eaaw8977 (2020).

92. L. Czech, P. Barbera, A. Stamatakis, Genesis and Gappa: Processing, analyzing and visualizing phylogenetic (placement) data. Bioinformatics. 36, 3263-3265 (2020).

93. C. Jeong et al., The genetic history of admixture across inner Eurasia. Nature Ecology \& Evolution. 3, 966-976 (2019).

94. I. Lazaridis et al., Genomic insights into the origin of farming in the ancient Near East. Nature. 536, 419-424 (2016).

95. S. Mallick et al., The Simons Genome Diversity Project: 300 genomes from 142 diverse populations. Nature. 538, 201-206 (2016).

96. N. Patterson et al., Ancient Admixture in Human History. Genetics. 192, 1065-1093 (2012).

97. A. V. Suvorov, A. Buzhilova, in OPUS: Interdisciplinary research in archeology. (IA RAN, Moscow, 2004), vol. 3, pp. 41-54.

98. A. Buzhilova, A. V. Suvorov, O. A. Krylovich, On the issue of the reconstruction of the way of life of the population of the late Stone Age (based on the materials of the Minino archaeological complex on the Kubenskoye Lake). KSIA. 222, 1-18 (2008).

99. R. E. Wood et al., Freshwater radiocarbon reservoir effects at the burial ground of Minino, northwest Russia. Radiocarbon. 55, 163177 (2013)

100. A. Buzhilova, A reconstruction of the lifestyle of early humans by natural-science methods. Herald of the Russian Academy of Sciences. 86, 297-304 (2016).

101. O. Bader, Finding of the human neanderthaloid calvarium near Khvalynsk, and the question of its age. Bull. Moscow association of nature sci., Dept. geol. 17 (1940).

102. G. Weinert, The Origin of Humanity (Biomedgiz, Moscow, 1935).

103. M. A. Gremyatsky, The problem of intermediate and transitional forms from the Neanderthal type of man to the modern one. Scientific notes of Moscow State University, Museum of Anthropology (1948).

104. O. Bader, Examination of the site of the discovery of the Khvalynskaya cranial vault. Brief Reports on scientific works of the Institute and Museum of Anthropology at Moscow State University (1941).

105. A. P. Osokov, Preliminary report on the discovery of a "graveyard" of post-Tertiary bones in the coastal gravel on the left bank of the Volga, between the River Sengilei and Novodevichy village. Bull. Moscow association of nature sci. (1913).

106. Okladnikov, Issledovaniya pamyatnikov kamennogo veka Tadzhikistana. Predvaritel'noe soobshchenie o rabotakh 1948, 1952$1954 \mathrm{gg}$. [The investigations of Stone Age sites in Tajikistan. Preliminary results of work 1948, 1952-1954]. Materials and investigations of USSR archaeology. 66, 12-71 (1958).

107. V. A. Ranov, G. F. Korobkova, Tutkaul - mnogosloinoe poselenie gissarskoi kultury v yuzhnom Tadjikistane [Tutkaul multilayered settlement site of the Gissar culture in southern Tajikistan]. Soviet Archaeology. 2, 133-147 (1971).

108. S. V. Shnaider, K. A. Kolobova, T. G. Filimonova, W. Taylor, A. I. Krivoshapkin, New insights into the Epipaleolithic of western Central Asia: The Tutkaulian complex. Quaternary International. 535, 139-154 (2020).

109. G. Mannino, Il riparo dell'Uzzo. Sicilia Archeologica (VI). 23, 21-39 (1973).

110. C. Collina, Le Néolithique ancien en Italie du sud: Evolution des Industries Lithiques entre VIIe et VIe Millénaire (Archaeopress, Oxford, 2015).

111. L. Conte, S. Tusa, in Atti della XLI Riunione Scientifica dell'Istituto Italiano di Preistoria e Protostoria. Istituto Italiano di Preistoria e Protostoria, Firenze (Istituto italiano di preistoria e protostoria, 2012).

112. M. Mannino, K. D. Thomas, M. Piperno, S. Tusa, A. Tagliacozzo, Fine-tuning the radiocarbon chronology of the Grotta dell'Uzzo (Trapani). Atti della Società per la Preistoria e Protostoria della Regione Friuli-Venezia Giulia. 15, 17-31 (2006).

113. M. A. Mannino et al., Marine resources in the Mesolithic and Neolithic at the Grotta dell'Uzzo (Sicily): Evidence from isotope analyses of marine shells. Archaeometry. 49, 117-133 (2007).

114. M. Piperno, S. Tusa, I. Valente, Campagne di scavo 1977 e 1978 alla Grotta dell'Uzzo (Trapani). Relazione preliminare e datazioni dei livelli mesolitici e neolitici. Sicilia Archeologica Trapani. 13, 49-64 (1980). 
115. M. Piperno, S. Tusa, Relazione preliminare sulla seconda campagna di scavi alla Grotta dell'Uzzo (Trapani). Sicilia archeologica. 21, 39-42 (1976).

116. A. Tagliacozzo, Archeozoologia della Grotta dell'Uzzo, Sicilia: Da un 'economia di caccia ad un'economia di pesca ed allevamento (Istituto poligrafico e zecca dello Stato, Roma, 1993), Supplemento del Bullettino di Paletnologia Italiana.

117. S. Tusa, Early Societies in Sicily: New developments in archaeological research (Accordia Research Centre, London, 1996), Accordia Specialist Studies on Italy.

118. S. Tusa, Papers in Italian Archaeology IV. Part II. Prehistory (BAR Publishing, Oxford, 1985), British Archaeological Reports, International Series.

119. M. A. Mannino et al., Climate-driven environmental changes around 8,200 years ago favoured increases in cetacean strandings and Mediterranean hunter-gatherers exploited them. Scientific reports. 5, 1-12 (2015).

120. S. Borgognini Tarli, A. Canci, M. Piperno, E. Repetto, Dati archeologici e antropologici sulle sepolture mesolitiche della Grotta dell'Uzzo (Trapani). Bullettino di Paletnologia Italiana. 84, 85-179 (1993).

121. R. Di Salvo, M. A. Mannino, V. Schimmenti, L. Sineo, K. D. Thomas, in Atti della XLI Riunione Scientifica dell'Istituto Italiano di Preistoria e Protostoria. Istituto Italiano di Preistoria e Protostoria, Firenze (2012), pp. 461-470.

122. C. Bronk Ramsey, Bayesian analysis of radiocarbon dates. Radiocarbon. 51, 337-360 (2009).

123. P. J. Reimer et al., The IntCal20 Northern Hemisphere radiocarbon age calibration curve ( $0-55 \mathrm{cal} \mathrm{kBP})$. Radiocarbon. 62, $725-$ 757 (2020).

124. B. S. Zhukov, The theory of chronological and territorial modifications of some Neolithic cultures of Eastern Europe according to the study of ceramics. Ethnography. 1, 54-77 (1929).

125. D. A. Krainov, Chronological framework of the Neolithic of the Upper Volga region. Brief reports of the Institute of Archeology, 57-62 (1978).

126. A. V. Engovatova, M. G. Zhilin, E. A. Spiridonova, Chronology of the Upper Volga Early Neolithic culture (based on the materials of the multilayer sites of the Volga-Oka interfluve). Russian archeology. 2, 11-21 (1998).

127. N. A. Tsvetkova, The beginning of the Neolithic era on the Upper Volga. Bulletin of St. Petersburg University of History. 24, 683717 (2019).

128. N. E. Zaretskaya, E. L. Kostyleva, "New data on the absolute chronology of the Lyalovo culture," Tver archaeological collection. Issue 8: Sat. Art. Tver. Tver Regional Museum of Local Lore (2011), pp. 175-183.

129. N. E. Zaretskaya, E. L. Kostyleva, Radiocarbon Chronology of the Initial Stage of the Upper Volga Early Neolithic Culture. Russian archeology. 1, 5-14 (2008).

130. Y. B. Tsetlin, Neolithic Center of the Russian Plain. Ornamentation of ceramics and the method of periodization of cultures. (Grif and K., Tula, 2008).

131. M. Ruppert-Dallmann, in Varia neolithica X, Go West! Kontakte zwischen Zentral- und Westeuropa, V. Becker, H. Bunnefeld, H. O’Neill, G. Woltermann, H.-J. Beier, R. Einicke, Eds. (Langenweissbach, 2020), pp. 69-75.

132. M. Küßner, K.-P. Wechler, in Siedlungsarchäologie des Endneolithikums und der frühen Bronzezeit, 11. Mitteldeutscher Archäologentagvom 18. Bis 20. Oktober 2018 in Halle (Saale), H. Meller, S. Friederich, M. Küßner, R. Stäuble, R. Risch, Eds. (2019), pp. 433-466.

133. Y. Boyadzhiev, I. Aslanis, S. Terzijska-Ignatova, V. Mazanova, in The Golden Fifth Millennium. Thrace and Its Neighbour Areas in the Chalcolithic. Proceedings of the International Symposium in Pazardzhik, Yundola, 26-30.10. 2009. Sofia, NIAM-BAS (2011), pp. 21-37.

134. V. Mazanova, in The Golden Fifth Millennium. Thrace and Its Neighbour Areas in the Chalcolithic. Proceedings of the International Symposium in Pazardzhik, Yundola, 26-30.10. 2009. Sofia, NIAM-BAS (2011), pp. 21-37.

135. В. И. Балабина, Т. Н. Мишина, Энеолитический могильник на телле Юнаците: Проблемы интерпретации. Российская археология, 47-64 (2012).

136. Р. Катинчаров, Р. Н. Я. Мерперт, В. С. Титов, В. Х. Мацанова, Л. И. Авилова, Селищна могила при с. Юнаците (Пазарджсиико). История на проучванията. Обща стратиграфия. Пласт А. Том I (София, 1995).

137. А. П. Бужилова, Ното sapiens: История болезни. Москва: Языки славянской культуры (Moscow, 2005).

138. D. Daněček, J. Klementová, Hostivice, k. Ú. Hostivice, výstavba logistického centra Tulipán Park (př. Č. 1/2007). Archeologické výzkumy Středočeského muzea v Roztokách u Prahy v roce 2007. Středočeský vlastivědný sborník. 26, 104-105 (2008).

139. J. Casana, Alalakh and the archaeological landscape of Mukish: The political geography and population of a Late Bronze Age kingdom. Bulletin of the American Schools of Oriental Research. 353, 7-37 (2009).

140. J. Lauinger, Following the Man of Yamhad: Settlement and Territory at Old Babylonian Alalah (Brill, Leiden, Boston, 2015), vol. 75 of Culture and history of the ancient Near East. 
141. E. Von Dassow, State and Society in the Late Bronze Age: Alalah Under the Mittani Empire (University Press of Maryland, Bethesda, 2008), vol. 17 of Studies on the civilization and culture of Nuzi and the Hurrians.

142. D. J. Wiseman, The Alalakh Tablets (British Institute of archaeology at Ankara, London, 1953).

143. K. A. Yener, in Across the border. Late bronze-iron age relations between Syria and Anatolia; proceedings of a symposium held at the Research Center of Anatolian Studies Koç University Istanbul May 31 - June 1 2010, K. A. Yener, Ed. (Peeters, 2013), Ancient Near Eastern Studies : Supplement, 42, pp. 11-36.

144. K. A. Yener, M. Akar, M. T. Horowitz, Eds., Tell Atchana, Alalakh. Volume 2: The Late Bronze II City: 2006-2010 Excavation Seasons (Koc University Press, Istanbul, 2019).

145. K. A. Yener, Ed., Tell Atchana, Ancient Alalakh: The 2003-2004 excavation seasons (Ege Yayınları, Istanbul, 2010).

146. K. A. Yener, The anatolian middle Bronze age kingdoms and Alalakh: Mukish, Kanesh and trade. Anatolian Studies, 151-160 (2007).

147. L. Woolley, A Forgotten Kingdom, Being a Record of the Results Obtained From the Excavation of Two Mounds, Atchana and Al Mina, in the Turkish Hatay (Penguin Books., Baltimore, 1953).

148. L. Woolley, C. J. Gadd, R. D. Barnett, “Alalakh: An account of the excavations at Tell Atchana in the Hatay; 1937-1949," Reports of the Research Committee of the Society of Antiquaries of London (18, Society of Antiquaries, Oxford, 1955).

149. T. Ingman, thesis, Koç University, Istanbul (2020).

150. T. Ingman, in Proceedings of the 15th Anniversary Symposium at the New Hatay Archaeology Museum, 10-12 June 2015, K. A. Yener, T. Ingman, Eds. (2020), pp. 389-406.

151. T. Ingman, in Overturning Certainties in Near Eastern Archaeology. A Festschrift in Honor of K. Aslihan Yener, C. Maner, M. T. Horowitz, A. S. Gilbert, Eds. (Brill, Leiden, Boston, 2017), vol. 90 of Culture and history of the ancient Near East, pp. 245-259.

152. M. Heinz, Kamid El-Loz. 4000 Years and More of Rural and Urban Life in the Lebanese Beqa'a Plain (Lebanese British Friends of the National Museum, Beyrouth, 2016), Archaeology \& History in the Lebanon.

153. R. Hachmann, Kāmid el-Lōz 1963-1981. German Excavations in Lebanon. Berytus. 37, 5-187 (1989).

154. R. Hachmann, Kumidi. Die Ergebnisse der Ausgrabungen auf dem Tell Kāmid el-Lōz in den Jahren 1963 bis 1981. Zeitschrift des Deutschen Palästina-Vereins. 114, 1-38 (1998).

155. M. Heinz, S. Kulemann-Ossen, J. Linke, E. Wagner, Kamid El-Loz: Intermediary Between Cultures: More Than 10 Years of Archaeological Research in Kamid El-Loz (1997 to 2007) (Ministère de la Culture, Direction Générale des Antiquités, Beyrouth, 2010), Bulletin d'archéologie et d'architecture libanaises. Hors-Série.

156. R. Hachmann, in Bericht über die Ergebnisse der Ausgrabungen in Kämid el-Lōz in den Jahren 1966 und 1967, R. Hachmann, Ed. (Habelt, Bonn, 1970).

157. R. Miron, in Bericht über die Ergebnisse der Ausgrabungen in Kāmid el-Lōz in den Jahren 1971 bis 1974, R. Hachmann, Ed. (Habelt, Bonn, 1982), vol. 32 of Saarbrücker Beiträge zur Altertumskunde, pp. 101-129.

158. E. Wagner-Durand, in Contextualising Grave Inventories in the Ancient Near East. Proceedings of a workshop at the London 7th ICAANE in April 2010 and an International Symposium in Tübingen in November 2010, both organised by the Tübingen Post-Graduate School "Symbols of the Dead", P. Pfälzner, H. Niehr, E. Pernicka, Eds. (Harrassowitz, Wiesbaden, 2014), pp. 51-72.

159. A. M. Tunzi Sisto et al., in Cosmology across Cultures, J. A. Rubiño-Martin, J. A. Belmonte, F. Prada, A. Alberdi, Eds. (2009), vol. 409 of ASP Conference Series, pp. 375-379.

160. A. M. Tunzi Sisto, in Atti del $21^{\circ}$ Convegno sulla Preistoria, Protostoria e Storia della Daunia, A. Gravina, Ed. (San Severo, 2001), vol. 21, pp. 253-274.

161. R. Peroni, B. Barbaro, A. Vanzetti, in Atti del $23^{\circ}$ Convegno sulla Preistoria, Protostoria e Storia della Daunia, A. Gravina, Ed. (San Severo, 2003), vol. 23, pp. 287-300.

162. A. M. Tunzi Sisto, Ipogei della Daunia: Preistoria di un territorio (Genzi - Banca del Monte di Foggia, Foggia, 1999).

163. P. Ratimorská, Keltské pohrebisko v Chotíne I. Západné Slovensko 8, 15-88 (1981).

164. P. C. Ramsl, Diversity of male identities in early and middle la Tène period cemeteries in Central Europe. Archaeologica Slovaca Monographiae - Studia XXXII (Nitra, 2020).

165. A. Bistáková, G. Březinová, P. C. Ramsl, Eds., in Multiple Identities in Prehistory, Early History and Presence. Proceedings of the SASPRO-workshops in Klement 2016 and Nitra 2018, Archaeologica Slovaca Monographiae - Communicationes XXIV. (Nitra, 2020).

166. M. Görföl, thesis, Szegedi Tudományegyetem, Szeged, Hungary (2017).

167. J. Gretzinger, S. Schiffels, in Diversity of Male Identities in Early and Middle La Tène Period Cemeteries in Central Europe. Archaeologica Slovaca Monographiae - Studia XXXII, P. C. Ramsl, Ed. (Nitra, 2020), pp. 215-220. 
168. G. Tóth, Report on the Anthropological Examination of the La Tène Age biritual Cemetery in Héteny (Chotín). Eruditio - Educatio. 10, 113-120 (2015).

169. A. Z. Beisenov et al., First Radiocarbon Chronology for the Early Iron Age Sites of Central Kazakhstan (Tasmola Culture and Korgantas Period). Radiocarbon. 58, 179-191 (2016).

170. A. Z. Beisenov, A. O. Ismagulova, E. Kitov, A. O. Kitova, Naselenie Tsentralnogo Kazahstana v I tys. Do n. E. [Population of Central Kazakhstan in the Ist millennium BC] (Almati: Institut arheologii, 2015).

171. A. Z. Beisenov, Sergi sakskoi epohi [Saka era earrings]. Tomsk State University Bulletin. 6, 121-128 (2014).

172. M. K. Kadyrbayev, in Drevnaya kul'tura Tsentral'nogo Kazahstana [Ancient culture of Central Kazakhstan], A. H. Margulan, K. A. Akishev, M. K. Kadyrbayev, A. M. Orazbayev, Eds. (Alma-Ata: Nauka, 1966), pp. 303-433.

173. Z. Samashev, in Materials of the International Archaeological conferences. (2019), pp. 385-394.

174. J. M. Toyne, L. A. Narváez, in Embattled Bodies, Embattled Places War in Pre-Columbian Mesoamerica and the Andes., A. K. Scherer, J. W. Verano, Eds. (Dumbarton Oaks Research Library and Collection, Washington D.C, 2014), pp. 341-364.

175. J. Crandall, El desarrollo espacial de las comunidades Chachapoyas bajo la dominación colonial Inka y Española. Boletín de Arqueología PUCP. 23, 283-311 (2017).

176. A. F. Kochkina, in Middle Volga Region in the Context of Medieval Russian History: At the Crossroads of Cultures (late 13th16th Centuries) (Ofort Publications, Samara, 2012), pp. 107-128.

177. K. I. Bos et al., Paleomicrobiology: Diagnosis and Evolution of Ancient Pathogens. Annual Review of Microbiology. 73, 639-666 (2019).

178. M. A. Spyrou, K. I. Bos, A. Herbig, J. Krause, Ancient pathogen genomics as an emerging tool for infectious disease research. Nat Rev Genet. 20, 323-340 (2019).

179. P. Kapli et al., Multi-rate Poisson tree processes for single-locus species delimitation under maximum likelihood and Markov chain Monte Carlo. Bioinformatics. 33, 1630-1638 (2017).

180. D. Serdari, E.-G. Kostaki, D. Paraskevis, A. Stamatakis, P. Kapli, Automated, phylogeny-based genotype delimitation of the Hepatitis Viruses HBV and HCV. PeerJ. 7, e7754 (2019).

181. P. Simmonds, S. Midgley, Recombination in the Genesis and Evolution of Hepatitis B Virus Genotypes. Journal of Virology. 79, $15467-15476$ (2005).

182. T. T. T. Huy, T. T. Ngoc, K. Abe, New Complex Recombinant Genotype of Hepatitis B Virus Identified in Vietnam. Journal of Virology. 82, 5657-5663 (2008).

183. F. Sugauchi et al., Hepatitis B Virus of Genotype B with or without Recombination with Genotype C over the Precore Region plus the Core Gene. Journal of Virology. 76, 5985-5992 (2002).

184. L. Pozzi et al., Primate phylogenetic relationships and divergence dates inferred from complete mitochondrial genomes. Molecular Phylogenetics and Evolution. 75, 165-183 (2014).

185. T. P. Cancio-Bello, M. de Medina, J. Shorey, M. D. Valledor, E. R. Schiff, An Institutional Outbreak of Hepatitis B Related to a Human Biting Carrier. J Infect Dis. 146, 652-656 (1982).

186. C. N. Shapiro et al., Hepatitis B virus transmission between children in day care. Pediatr Infect Dis J. 8, 870-875 (1989).

187. N. Amano et al., Subsistence strategies and environment in Late Pleistocene-Early Holocene Eastern Java: Evidence from Braholo Cave. Quaternary International. 416, 46-63 (2016).

188. O. Wedage et al., Specialized rainforest hunting by Homo sapiens $\sim 45,000$ years ago. Nat Commun. 10, 1-8 (2019).

189. S. Y. W. Ho, S. Duchêne, Dating the emergence of human pathogens. Science. 368, 1310-1311 (2020).

190. M. R. McLennan, K. J. Hockings, in Problematic Wildlife: A Cross-Disciplinary Approach, F. M. Angelici, Ed. (Springer International Publishing, Cham, 2016), pp. 373-394.

191. B. G. Ogunjemite, T. A. Ashimi, Hunting and Trading in the Nigerian Chimpanzee (Pan Troglodytes Vellerosus) in GashakaMambilla Region, Nigeria. Ethiopian Journal of Environmental Studies and Management. 3, 62-69 (2010).

192. R. Phoonjampa, W. Y. Brockelman, Survey of pileated gibbon Hylobates pileatus in Thailand: Populations threatened by hunting and habitat degradation. Oryx. 42, 600-606 (2008).

193. M. Worobey, G.-Z. Han, A. Rambaut, A synchronized global sweep of the internal genes of modern avian influenza virus. Nature. 508, 254-257 (2014).

194. P. de B. Damgaard et al., 137 ancient human genomes from across the Eurasian steppes. Nature. 557, 369-374 (2018).

195. W. A. Goffart, Barbarian tides: The migration age and the later Roman Empire (University of Pennsylvania Press, Philadelphia, 2006). 
196. C. Alonso Fernández, J. Jiménez Echevarría, in 5. ${ }^{\circ}$ Congresso do Neolítico Peninsular. Actas: Faculdade de Letras da Universidade de Lisboa, 7-9 abril 2011 (2015), pp. 540-546.

197. A. Szécsényi-Nagy et al., The maternal genetic make-up of the Iberian Peninsula between the Neolithic and the Early Bronze Age. Scientific Reports. 7, 15644 (2017).

198. C.-C. Wang et al., Ancient human genome-wide data from a 3000-year interval in the Caucasus corresponds with eco-geographic regions. Nat Commun. 10, 1-13 (2019).

199. E. Skourtanioti et al., Genomic History of Neolithic to Bronze Age Anatolia, Northern Levant, and Southern Caucasus. Cell. 181, 1158-1175.e28 (2020).

200. B. Danielisova, M. Langová, in Akten der Internationalen Tagung in Frankurt a. M. Vom 3. Bis 5. Februar 2012 (Frankfurt a. M., 2013), pp. 239-250.

201. D. Baird et al., Agricultural origins on the Anatolian plateau. PNAS. 115, E3077-E3086 (2018).

202. V. I. Khartanovich, A. V. Zubova, V. G. Moiseev, in Kola Oleneostrovsky cemetery: 1925-2013., E. M. Kolpakov, A. I. Murashkin, V. I. Khartanovich, V. Y. Shumkin, Eds. (Saint-Petersburg, Vologda, 2019), pp. 353-405.

203. T. C. Lamnidis et al., Ancient Fennoscandian genomes reveal origin and spread of Siberian ancestry in Europe. Nature Communications. 9, 5018 (2018).

204. K. Nägele et al., Genomic insights into the early peopling of the Caribbean. Science. 369, 456-460 (2020).

205. Y. Chinique de Armas et al., Starch analysis and isotopic evidence of consumption of cultigens among fisher-gatherers in Cuba: The archaeological site of Canímar Abajo, Matanzas. Journal of Archaeological Science. 58, 121-132 (2015).

206. M. Roksandic et al., Radiocarbon and Stratigraphic Chronology of Canímar Abajo, Matanzas, Cuba. Radiocarbon. 57, 755-763.

207. V. Villalba-Mouco et al., Survival of Late Pleistocene Hunter-Gatherer Ancestry in the Iberian Peninsula. Current Biology. 29, 1169-1177.e7 (2019).

208. D. Chala-Aldana et al., Investigating mobility and highland occupation strategies during the Early Holocene at the Cuncaicha rock shelter through strontium and oxygen isotopes. Journal of Archaeological Science: Reports. 19, 811-827 (2018).

209. C. Posth et al., Reconstructing the Deep Population History of Central and South America. Cell. 175, 1185-1197.e22 (2018).

210. N. Nicklisch, Spurensuche am Skelett. Paläodemografische und epidemiologische Untersuchungen an neolithischen und frühbronzezeitlichen Bestattungen aus dem Mittelelbe-Saale-Gebiet im Kontext populationsdynamischer Prozesse (Landesamt für Denkmalpflege und Archäologie Sachsen-Anhalt, Halle, 2017).

211. L. Amkreutz et al., What lies beneath ... Late Glacial human occupation of the submerged North Sea landscape. Antiquity. 92, 2237 (2018).

212. H. Peeters, L. Amkreutz, in The Archaeology of Europe's Drowned Landscapes, G. Bailey, N. Galanidou, H. Peeters, H. Jöns, M. Mennenga, Eds. (Springer International Publishing, Cham, 2020), Coastal Research Library, pp. 157-174.

213. J. van der Plicht, L. W. S. W. Amkreutz, M. J. L. T. Niekus, J. H. M. Peeters, B. I. Smit, Surf'n Turf in Doggerland: Dating, stable isotopes and diet of Mesolithic human remains from the southern North Sea. Journal of Archaeological Science: Reports. 10, 110-118 (2016).

214. I. Mathieson et al., Genome-wide patterns of selection in 230 ancient Eurasians. Nature. 528, 499-503 (2015).

215. C. Tejedor-Rodríguez et al., Investigating Neolithic caprine husbandry in the Central Pyrenees: Insights from a multi-proxy study at Els Trocs cave (Bisaurri, Spain). PLOS ONE. 16, e0244139 (2021).

216. P. Lefranc, H. Réveillas, Y. Thomas, in Death as archaeology of transition: Thoughts and materials: Papers from the 2nd International Conference of transition archaeology: Death archaeology, Evora, Portugal, 29 April-1st May 2013, L. Rocha, P. BuenoRamirez, G. Branco, Eds. (2015), vol. 2708, pp. 131-144.

217. M. Rivollat et al., When the Waves of European Neolithization Met: First Paleogenetic Evidence from Early Farmers in the Southern Paris Basin. PLOS ONE. 10, e0125521 (2015).

218. M. Lipson et al., Parallel palaeogenomic transects reveal complex genetic history of early European farmers. Nature. 551, 368-372 (2017).

45 219. A. Mittnik et al., The genetic prehistory of the Baltic Sea region. Nature Communications. 9, 442 (2018).

220. E. Bragayrac, in Huari administrative structure: Prehistoric monumental architecture and state government, W. H. Isbell, G. F. McEwan, Eds. (Dumbarton Oaks, Washington, D.C., 1991), pp. 71-80.

221. N. N. Gurina, The Cemetery of Olenii Ostrov. Materials on the History of Archaeology of the USSR. 47 (1956). 
223. S. Schiffels et al., Iron Age and Anglo-Saxon genomes from East England reveal British migration history. Nature Communications. 7, 10408 (2016).

224. G. Brandt et al., Ancient DNA Reveals Key Stages in the Formation of Central European Mitochondrial Genetic Diversity. Science. 342, 257-261 (2013).

225. P. Brotherton et al., Neolithic mitochondrial haplogroup H genomes and the genetic origins of Europeans. Nature communications. 4, 1-11 (2013).

226. I. Olalde et al., The Beaker phenomenon and the genomic transformation of northwest Europe. Nature. 555, 190-196 (2018).

227. Л. Ильюков, С. Лукьяшко, Новые памятники скифского времени на Нижнем Дону. Донские древности, 57-79 (1994).

228. G. Valverde et al., Ancient DNA Analysis Suggests Negligible Impact of the Wari Empire Expansion in Peru's Central Coast during the Middle Horizon. PLOS ONE. 11, e0155508 (2016).

229. A. Sagona et al., Excavations at Samtavro, 2008-2009: An interim report. Ancient Near Eastern Studies. 47, 1-135 (2010).

230. M. M. Gerasimova, Paleoanthropology of North Ossetia in connection with the problem of ossetian origins. Etnograficheskoe obozrenie. 3, 51-62 (1994).

231. J. H. Marcus et al., Genetic history from the Middle Neolithic to present on the Mediterranean island of Sardinia. Nature Communications. 11, 939 (2020).

232. A. E. Mann et al., Differential preservation of endogenous human and microbial DNA in dental calculus and dentin. Scientific reports. 8, 1-15 (2018).

233. K. Massy, Die Gräber der Frühbronzezeit im südlichen Bayern. Untersuchungen zu den Bestattungs-und Beigabensitten sowie gräberfeldimmanenten Strukturen (Michael Lassleben, 2018).

20 234. A. Mittnik et al., Kinship-based social inequality in Bronze Age Europe. Science. 366, 731-734 (2019).

235. C. Parker et al., A systematic investigation of human DNA preservation in medieval skeletons. Scientific Reports. 10, 18225 (2020).

236. J. W. Verano, in The 1912 Yale Peruvian Scientific Expedition Collections from Machu Picchu: Human and Animal Remains, R. L. Burger, L. C. Salazar, Eds. (Dept. of Anthropology, Yale University Division of Anthropology, Peabody Museum of Natural History, New Haven, CT, 2003), pp. 65-117.

237. M. Ernée et al., Mikulovice: Early Bronze Age Cemetery on the Amber Road (Institute of Archaeology of the Czech Academy of Sciences, Prague, 2020), Památky archeologické - supplementum.

238. I. Jadin, M. Carpentier, La sépulture mésolithique du Petit Ri à Malonne (Namur, Belgique). Contexte archéologique et position chronologique. Anthropologie et préhistoire. 105, 65-82 (1994).

239. A. A. Kalmykov, N. Berezina, M. V. Dobrovoskaya, J. Gresky, A. P. Bushilova, The Burial of a Lola Smelter in the Stavropol Region. Kratkie Soobsheniya Institua Arkheologii, 64-79 (2018).

240. R. Mortimer, D. Sayer, R. Wiseman, in Life on the Edge: Social and political frontiers in early medieval Europe, S. Semple, C. Orsini, S. Mui, Eds. (2017), pp. 305-316.

241. M. Kostka, L. Smejtek, An Old Únětice cemetery near Řepná street in Prague-Ďáblice. Archeologie ve středních Čechách. 6, 679718 (2012).

242. M. Rivollat et al., Ancient genome-wide DNA from France highlights the complexity of interactions between Mesolithic huntergatherers and Neolithic farmers. Science Advances. 6, eaaz5344 (2020).

243. K. von Heyking, thesis, Universitätsbibliothek der Ludwig-Maximilians-Universität (2013).

244. A. Gow, G. Rossin, “Sedgeford Historical and Archaeological Research Project 2009 Annual Report” (2009)..

245. N. Shishlina et al., Subsistence strategies of Meshchera lowlands populations during the Eneolithic period - The Bronze Age: Results from a multidisciplinary approach. Journal of Archaeological Science: Reports. 10, 74-81 (2016).

246. M. V. Dobrovolskaya, N. A. Makarov, M. A. Samorodova, Mobility of the Suzdal Opolye Settlers in 900-1150 AD. Archaeology, Ethnology \& Anthropology of Eurasia. 48, 106-115 (2021).

247. O. del Castillo, thesis, Escuela Nacional de Antropología e Historia, Mexico (2000).

248. K. Van de Vijver, F. Kinnaer, S. Depuydt, in The Urban Graveyard: Archaeological Perspectives, R. M. R. Van Oosten, R. Schats, F. Kerri, M. Arts, J. Bouwmeester, Eds. (Sidestone Press, Leiden, 2018), pp. 239-287.

249. R. Krauß et al., Chronology and development of the Chalcolithic necropolis of Varna I. Documenta Praehistorica. 44, 282-305 (2017).

250. M. Dobeš, P. Limburskỳ, Ž. Brnić, Pohřebiště staršiho eneolitu a šňurové keramiky ve Vliněvsi (Archeologickỳ ústav AV ČS, Praha, 2013), Archeologické studijní materiály.

251. P. Limburskỳ et al., Pohřebni areály únětické kultury ve Vliněvsi (Archeologickỳ ústav AV ČR, Praha, 2018). 
252. S. Saintot et al., in De la tombe au territoire, 11èmes Rencontres méridionales de Préhistoire Récente (AEP, 2016), vol. 1, pp. 407421.

253. C. Knipper et al., Female exogamy and gene pool diversification at the transition from the Final Neolithic to the Early Bronze Age in central Europe. PNAS. 114, 10083-10088 (2017).

254. J. Somers, C. Cooper, A. Alterauge, S. Lösch, A Medieval/Early Modern Alpine Population from Zweisimmen, Switzerland: A Comparative Study of Anthropology and Palaeopathology. International Journal of Osteoarchaeology. 27, 958-972 (2017).

\section{Acknowledgements}

We thank Michaela Harbeck, Luca Bondioli and Henri Duday for their contribution to the archaeological interpretation, Renate and Henrike Heyne for comments concerning clinical manifestation of hepatitis B infections and Michelle O'Reilly for her help on the design of the figures. Funding: the research was funded by the Max Planck Society, the European Research Council (ERC) under the European Union's Horizon 2020 research and innovation program (771234 - PALEoRIDER, to WH; 805268 - CoDisEASe to KBos; 834616 15 ARCHCAUCASUS to SH), the ERA.NET RUS Plus - S\&T programm of the European Union's Seventh Framework Programme (277 - BIOARCCAUCASUS to SRe and SH), the Werner Siemens Stiftung ("Paleobiochemistry", to CW), the Award Praemium Academiae of the Czech Academy of Sciences (to ME), the Institute of Archaeology of the Czech Academy of Sciences (RVO 67985912, to MDobe), the Russian Foundation for Basic Research (19-0900354a, to MKK and VVK; 19-78-10053 to SSh), the German Research Foundation (DFGHA-5407/4-1 - INTERACT to WH and RE2688/2 to SRe), the French National Research Agency (ANR-17-FRAL-0010 - INTERACT, to MFD, MRi, SRo, SSai, DBi, and PLe), the Ministry of Education and Science of the Republic of Kazakhstan (AP08856654 to LBD, LM and EKh) and the Wenner-Gren Dissertation Fieldwork Grant (9558 to SSab). Author

25 contributions: DK and JK initiated and supervised the study. SF, VSc, VK, MKK, MSC, VVK, AAKh, AAC, DAS, AFK, CTR, IGMdL, HAM, RGP, JIRG, JN, SRo, SK, SSai, EKa, ABB, PV, PLi, MKo, LLo, EP, RC, AL, RM, YCdA, STHG, DIHZ, JP, DBi, PLe, ARK, VEM, LLa, 
MZ, JFB, ML, AD, TI, GCA, MPdMI, AR, ASp, SB, SSal, EDZ, DVV, KvH, RLB, LCS, LA, MN, ER, CAF, VSl, AAKa, BCA, EB, MAC, MS, RK, JJE, MFr, SSh, PdK, EA, KVdV, LFS, TAT, SL, MDobr, NM, CR, MVT, CS, PCR, MA, KAY, ECB, FC, VMa, PU, KR, DBa, PS, LMM, MRo, HS, DCSG, NS, YSE, FH, YB, KBoy, MKü, DS, PO, RSk, MRG, AB, LBD, AZB, ZS, KMas, MMa, VMo, KMan, SRe, SH, EPK, MDobe, ME, HM and KWA conducted the archaeological/anthropological work or the curation of the archeological material JK, WH, CPo, KBos, PWS, SSc, CW, MFD, OB, EKh, EFD, BL, ASa, EB, EKG, LM and MRi organized the sample collection for genetic analyses RB, LP, MAS, FA, RSt, AW, AM, VVM, GUN, MRi, MSvdL, KMaj, RIT, LM, AG, SP, SSab, MMi, JG, EAN, TF, KN, CPa, MKe,

10 EKG, MFe, SE, ES, KG, GAGR, DIHZ, BL, EFD, OB, MFD and WH participated in the laboratory work, sample management, and gathering of contextual information. AK, FMK, MAS and RH performed HBV screening of the sequencing data, which was supervised by AH. $\mathrm{AK}$ and KP performed the bioinformatic analyses. AK and DK performed the phylogenetic analyses. LP performed the human population genetics analyses. AK and ABR performed the 15 statistical analyses. All authors contributed to the interpretation of the data. AK wrote the first version of the manuscript which was edited by DK, JK, WH, AH, CPo, KBos, PWS, SSc, CW, FvB, MP, LP, RB, FMK and MAS, and all authors contributed to its improvement. Competing interests: Authors declare that they have no competing interests. Data and materials availability: The sequencing data generated in this study has been deposited at the European 20 Nucleotide Archive (http://www.ebi.ac.uk/ena/data/view/PRJEB45699). Complete HBV sequence alignments are available in the supplementary materials.

\section{Supplementary Materials}

Materials and Methods 
Supplementary Text

Figs. S1 to S10

Tables S1 to S5

References (59-254)

$5 \quad$ Data S1 to S4 


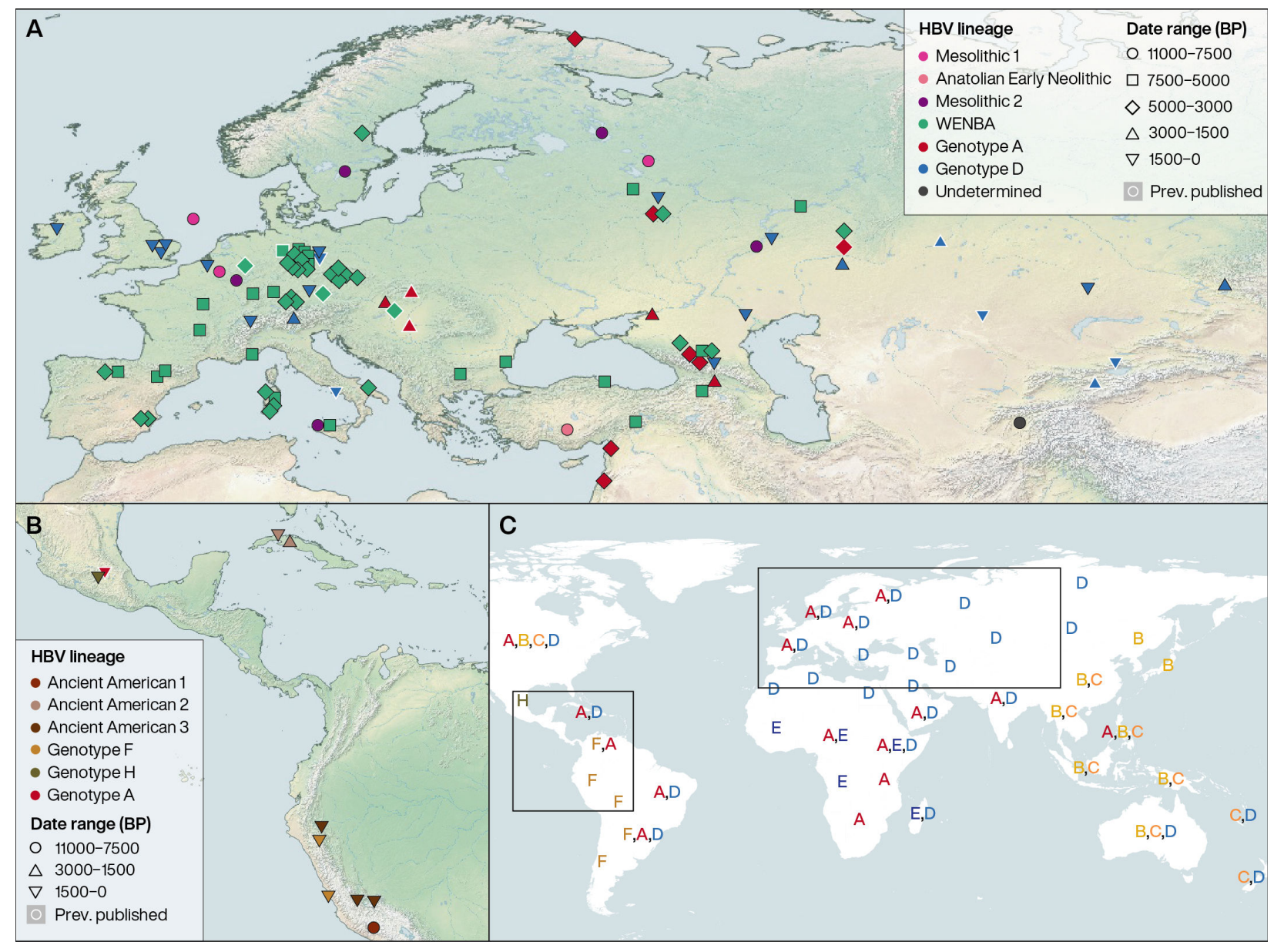

Fig. 1: Geographic location, time period, and lineage of ancient HBV genomes from (A)

Eurasia and (B) the Americas. (C) Main distribution of present-day HBV genotypes [adapted from (4), (14)]. 

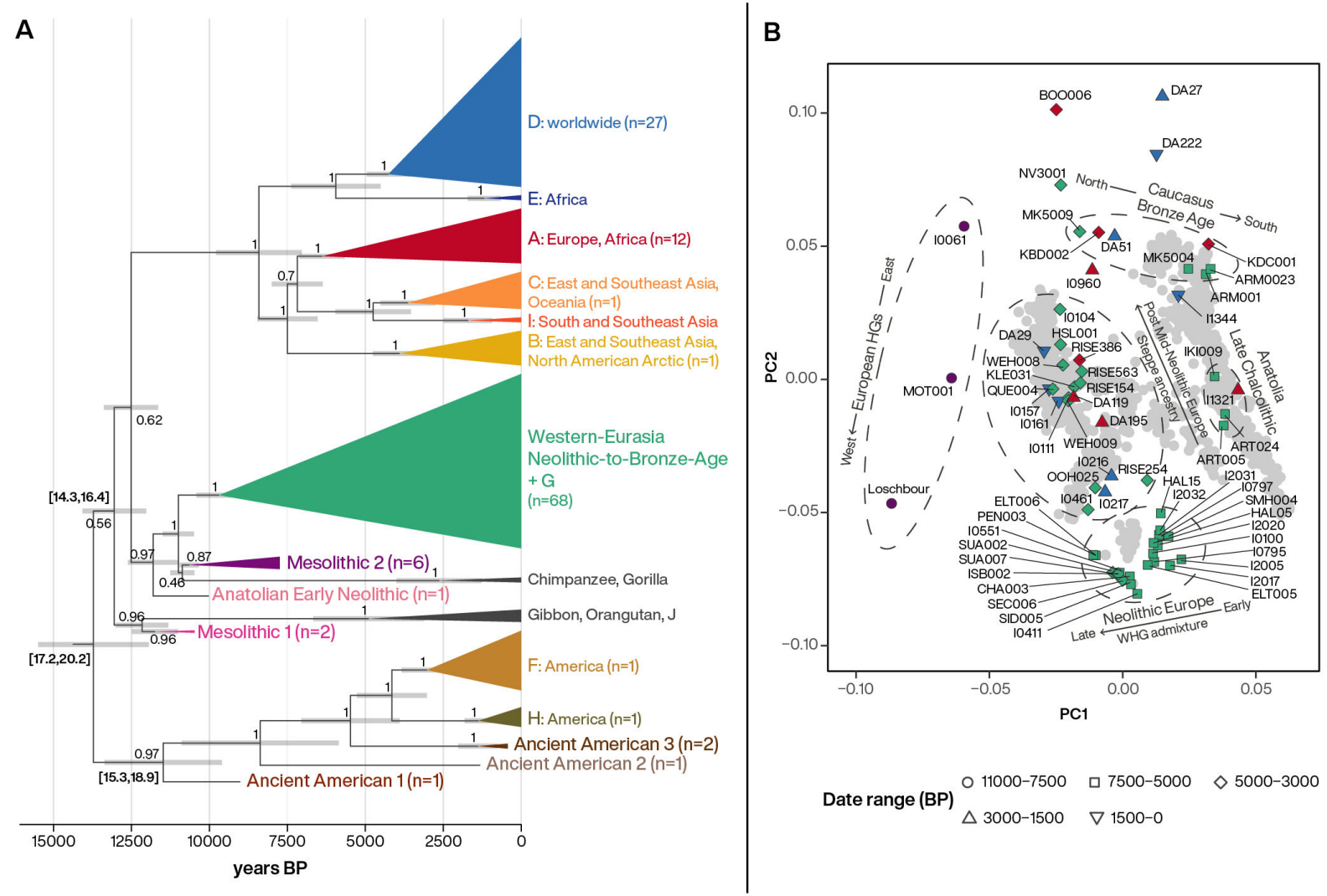

Fig. 2. HBV phylogeny and genetic profile of infected individuals. (A)Time-calibrated phylogenetic tree of HBV obtained using a skyline coalescent tree prior and a lognormal relaxed clock. Main clades were collapsed and annotated with their typical present-day geographic location and the number of ancient genomes they contain. Posterior node supports and date estimates (grey bars, indicating 95\%HPD) are reported. Additional time-intervals written on deep nodes are 95\% HPD estimates obtained with a time-dependent rate model. (B) Principal components analysis plot of modern and ancient western Eurasians summarizing the genetic variation of a subset of individuals for which human genetic data was available. Individuals are colored according to the lineage of the HBV strain they carried, as in the tree. 
A

B

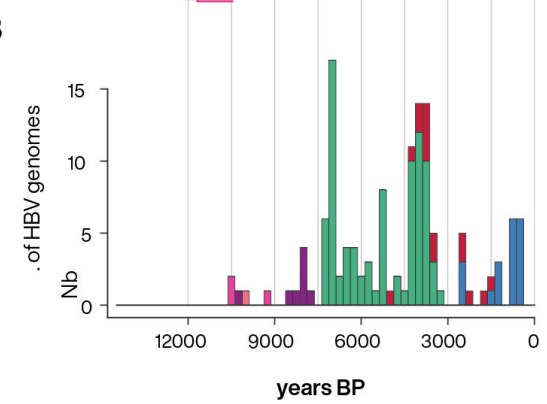

C

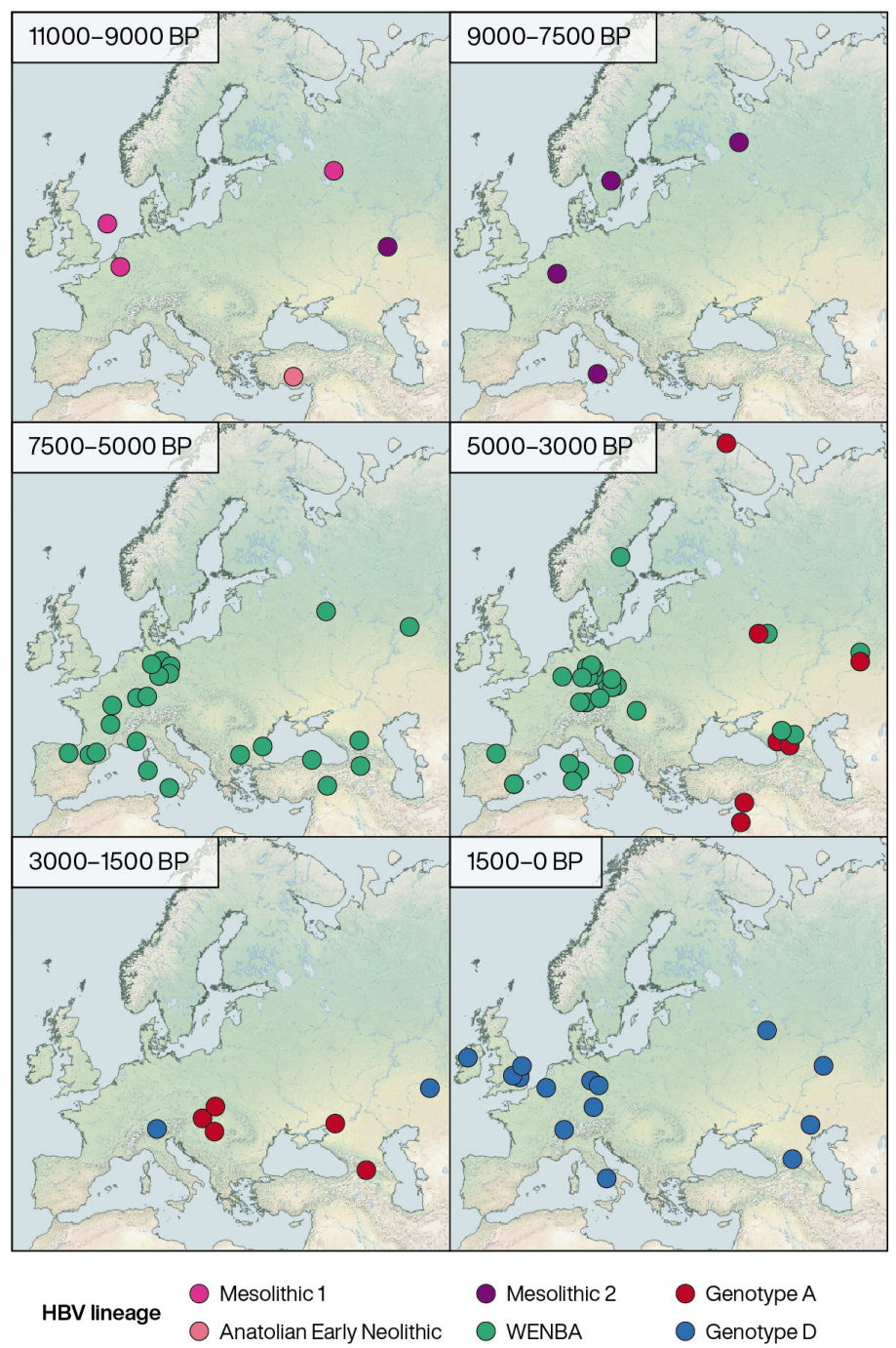

Fig. 3. Spatiotemporal distribution of ancient western Eurasian HBV strains. (A) Timecalibrated phylogenetic tree (Eurasian branch). Lineages containing ancient HBV genomes are colored. (B) Histogram showing the number of recovered ancient HBV genomes belonging to each lineage through time. (C) Geographic distribution of ancient HBV genomes within different time-periods, colored by lineage. 